ARTICLE

DOI: $10.1038 /$ s41467-018-05613-7

\title{
A selective inhibitor of ceramide synthase 1 reveals a novel role in fat metabolism
}

Nigel Turner ${ }^{1}$, Xin Ying Lim²,3, Hamish D. Toop (D) ${ }^{4}$, Brenna Osborne (i) ${ }^{1}$, Amanda E. Brandon 5 , Elysha N. Taylor ${ }^{4}$, Corrine E. Fiveash', Hemna Govindaraju1, Jonathan D. Teo ${ }^{3}$, Holly P. McEwen ${ }^{3}$, Timothy A. Couttas ${ }^{3}$, Stephen M. Butler ${ }^{4}$, Abhirup Das ${ }^{1}$, Greg M. Kowalski (i] ${ }^{6}$, Clinton R. Bruce ${ }^{6}$, Kyle L. Hoehn (1) 7, Thomas Fath ${ }^{1,10,}$ Carsten Schmitz-Peiffer ${ }^{8}$, Gregory J. Cooney ${ }^{5}$, Magdalene K. Montgomery', Jonathan C. Morris ${ }^{4}$ \& Anthony S. Don ${ }^{3,9}$

Specific forms of the lipid ceramide, synthesized by the ceramide synthase enzyme family, are believed to regulate metabolic physiology. Genetic mouse models have established C16 ceramide as a driver of insulin resistance in liver and adipose tissue. C18 ceramide, synthesized by ceramide synthase 1 (CerS1), is abundant in skeletal muscle and suggested to promote insulin resistance in humans. We herein describe the first isoform-specific ceramide synthase inhibitor, P053, which inhibits CerS1 with nanomolar potency. Lipidomic profiling shows that P053 is highly selective for CerS1. Daily P053 administration to mice fed a highfat diet (HFD) increases fatty acid oxidation in skeletal muscle and impedes increases in muscle triglycerides and adiposity, but does not protect against HFD-induced insulin resistance. Our inhibitor therefore allowed us to define a role for CerS1 as an endogenous inhibitor of mitochondrial fatty acid oxidation in muscle and regulator of whole-body adiposity.

\footnotetext{
${ }^{1}$ School of Medical Sciences, UNSW Sydney, Sydney 2052 NSW, Australia. ${ }^{2}$ Prince of Wales Clinical School, Faculty of Medicine, UNSW Sydney, Sydney 2052 NSW, Australia. ${ }^{3}$ Centenary Institute, The University of Sydney, Sydney 2006 NSW, Australia. ${ }^{4}$ School of Chemistry, UNSW Sydney, Sydney 2052 NSW, Australia. ${ }^{5}$ Sydney Medical School, Charles Perkins Centre, University of Sydney, Sydney 2006 NSW, Australia. ${ }^{6}$ Institute for Physical Activity and Nutrition, School of Exercise and Nutrition Sciences, Deakin University, Burwood 3125 VIC, Australia. ${ }^{7}$ School of Biotechnology and Biomolecular Sciences, UNSW Sydney, Sydney 2052 NSW, Australia. ${ }^{8}$ Garvan Institute of Medical Research, Sydney 2010 NSW, Australia. ${ }^{9}$ NHMRC Clinical Trials Centre, Sydney Medical School, The University of Sydney, Sydney 2006 NSW, Australia ${ }^{10}$ Present address: Department of Biomedical Sciences, Macquarie University, Sydney, NSW 2109, Australia. These authors contributed equally: Nigel Turner, Xin Ying Lim. Correspondence and requests for materials should be addressed to N.T. (email: n.turner@unsw.edu.au) or to J.C.M. (email: jonathan.morris@unsw.edu.au) or to A.S.D. (email: anthony.don@sydney.edu.au)
} 
C eramide is the central metabolite of the sphingolipid family, structurally comprised of a sphingoid base-generally 18 carbon dihydrosphingosine or sphingosine-with a variable length fatty acyl side-chain ${ }^{1,2}$. Ceramides form the lipid backbone to which a diverse array of headgroup structures are conjugated, forming sphingomyelin (SM), glucosyl- and galactosylceramide (HexCer), gangliosides, and globosides ${ }^{2,3}$. Ceramides are also signalling molecules that regulate ER stress ${ }^{4}$, apoptosis ${ }^{5}$, insulin sensitivity ${ }^{1,6}$, and other physiological functions. At the molecular level, ceramides influence membrane fluidity, modulating the compartmentalisation of cellular signalling processes ${ }^{7,8}$, and directly activate specific protein kinases and phosphatases such as the ubiquitous phosphatase $\mathrm{PP} 2 \mathrm{~A}^{1,3,8}$. Increased ceramide levels are heavily implicated in the pathogenesis of insulin resistance ${ }^{9-12}$ and neurodegenerative conditions ${ }^{13}$, whilst decreased levels fuel cancer cell resistance to therapy ${ }^{3}$.

Ceramide synthesis in mammals is catalysed by a family of six ceramide synthases (CerS1-6). These enzymes transfer a variable length fatty acyl-coenzyme A (CoA) to the amine group of a sphingoid base ${ }^{1}$. Studies employing genetic manipulations have demonstrated that different CerS isoforms exhibit strong preference for fatty acyl-CoAs with differing carbon chain lengths. CerS1 exclusively uses 18 carbon (C18) fatty acids, forming C18 (d18:1/ 18:0) ceramide $^{14-16}$, whilst CerS2 preferentially forms d18:1/24:0 (C24:0) and d18:1/24:1 (C24:1) ceramides ${ }^{16-18}$. Thus, ceramide is not a single lipid entity; rather it is a family of signalling lipids with important physiological functions, and variation in the ceramide acyl-chain dramatically influences the biological properties of these lipids. Insulin resistance caused by a HFD is alleviated by CerS5 or CerS6 gene deletion, which prevents C16 ceramide synthesis in liver and adipose tissue $e^{9,10,12}$. C16 and shorter chain ceramides antagonise the insulin receptor- $\mathrm{PI}_{3}$ kinase-Akt signalling pathway and inhibit fat utilisation as an energy source via $\beta$-oxidation ${ }^{1,7,9,19}$. In direct contrast, $\mathrm{C} 24$ ceramides synthesized by CerS2 protect against insulin resistance ${ }^{6,9,20}$. The synthesis of ceramides and other sphingolipids is regulated by availability of fatty acyl-CoA substrates, particularly palmitoyl-CoA derived from the common saturated fatty acid palmitate ${ }^{2,21}$. As such, ceramide synthesis may act as a direct metabolic sensor of fatty acid availability, feeding back to regulate metabolic processes.

Another ceramide species implicated in insulin resistance is C18:0 $0^{11,22,23}$. CerS1 and its product C18 ceramide are highly abundant in skeletal muscle $(\mathrm{SkM})^{1,18}$. Studies comparing obese insulin resistant and insulin sensitive subjects, exercise interventions in type 2 diabetes, and induction of insulin resistance in mice, all show an association between muscle C18:0 ceramide and impairments in insulin action ${ }^{11,22,24}$. Although a relatively minor species in plasma, circulating C18 ceramide is also very significantly correlated with body mass index ${ }^{25}$ and visceral fat mass $^{22}$. Similarly, C18 ceramide in SkM is positively correlated with visceral fat, as well as blood pressure ${ }^{22}$.

Selective inhibition of CerS5, CerS6, and/or CerS1 would therefore be predicted to produce significant benefits for metabolic health, whilst CerS2 inhibition would have detrimental effects. However, isoform-specific CerS inhibitors with sufficient potency, selectivity, and bioavailability for in vivo use have not yet been developed ${ }^{26,27}$. This report describes the discovery and characterisation of the first potent, isoform-selective CerS inhibitor, specifically targeting CerS1. CerS1 inhibition is shown to promote fatty acid oxidation in SkM and reduce overall adiposity in mice fed a HFD.

\section{Results}

Development of a potent and selective CerS1 inhibitor. To develop isoform-selective CerS inhibitors, we started with the multiple sclerosis drug Fingolimod (FTY720, Gilenya), which is an analogue of the endogenous lipid sphingosine ${ }^{28}$. Following its phosphorylation in vivo, Fingolimod is a potent agonist of sphingosine 1-phosphate receptors, however the nonphosphorylated pro-drug also exhibits non-selective inhibition of ceramide synthases as an off-target effect ${ }^{29,30}$. We recently established that the non-phosphorylatable, chiral FTY720 analogue AAL(S) and its benzyl tail derivative G024 (Fig. 1a, compound 1), show limited selectivity for CerS1 over other CerS isoforms ${ }^{27}$. However, their degree of selectivity for CerS1 is poor and, importantly, these compounds do not selectively reduce $\mathrm{C} 18$ ceramide levels in cultured cells. Using the Topliss tree as a guide $^{31,32}$ we examined variations of the benzyl tail of G024, resulting in the identification of (S)-2-amino-4-(4-(3,4-dichlorobenzyloxy)phenyl)-2-methylbutan-1-ol (P053, [compound 2]) as a potent and selective CerS1 inhibitor (Fig. $1 \mathrm{a}, \mathrm{b}$ ). The $\mathrm{IC}_{50}$ for inhibition of CerS1 with P053 was $0.5 \mu \mathrm{M}$, an order of magnitude lower than that of G024 (Table 1). IC 50 's for inhibition of CerS2, CerS4, CerS5, and CerS6 by P053 were all at least one order of magnitude higher than for CerS1, demonstrating strong selectivity for CerS1 over other CerS isoforms (Fig. 1b and Table 1). The $\mathrm{IC}_{50}$ for P053 on CerS1 was similar to that of the potent but non-selective CerS inhibitor Fumonisin B1 (FB1) ${ }^{33}$, which inhibited all CerS isoforms with sub-micromolar $\mathrm{IC}_{50}$ (Table 1). As shown previously by Lahiri et al. ${ }^{29}$ for CerS2, CerS1 activity as
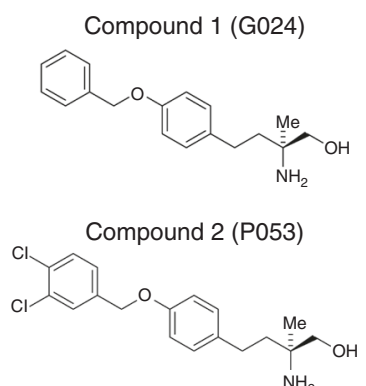

$\mathrm{NH}_{2}$ b

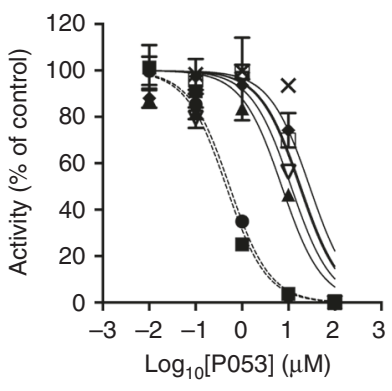

C

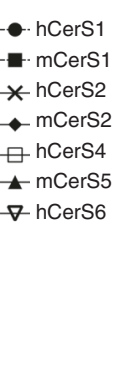

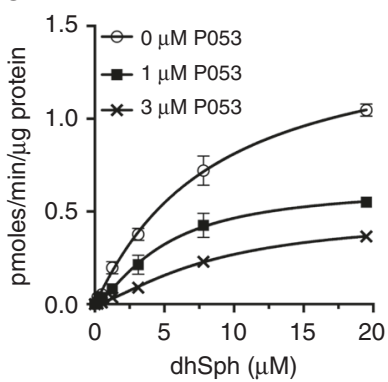

\begin{tabular}{|c|c|c|c|}
\hline & $0 \mu \mathrm{M}$ & $1 \mu \mathrm{M}$ & $3 \mu \mathrm{M}$ \\
\hline$V_{\max }$ & 1.5 & 0.63 & 0.48 \\
\hline$K_{\text {half }}$ & 8.2 & 4.9 & 8.4 \\
\hline
\end{tabular}

d

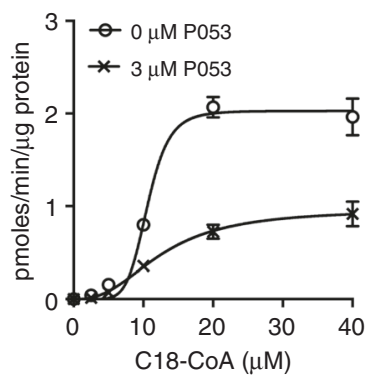

\begin{tabular}{|c|c|c|}
\hline & $0 \mu \mathrm{M}$ & $3 \mu \mathrm{M}$ \\
\hline$V_{\max }$ & 2.03 & 0.96 \\
\hline$K_{\text {half }}$ & 10.6 & 12.6 \\
\hline
\end{tabular}

Fig. 1 P053 is a selective inhibitor of CerS1. a Structure of G024 [1] and P053 [2]. b Activity of CerS isoforms as a function of P053 concentration ( $n=3$ for each concentration, mean $\pm S E M)$. c, d CerS1 activity as a function of $\mathbf{c}$ dihydrosphingosine or $\mathbf{d}$ C18:0-CoA concentration. Calculated $V_{\text {max }}$ and $K_{\text {half }}$ values are below the graphs. Graphs show mean $\pm \operatorname{SEM}(n=3$ for each concentration), and the non-competitive inhibition was confirmed in three independent experiments for each substrate 


\begin{tabular}{|llllllll}
\hline \multicolumn{2}{l}{ Table $\mathbf{1}$ IC } \\
\end{tabular}

Calculated $\mathrm{IC}_{50}$ values $(\mu \mathrm{M})$ for inhibition of different human $(\mathrm{h})$ or murine $(\mathrm{m})$ CerS isoforms by P053, G024, FTY720, and FB1. IC 50 values were calculated using an inhibitor range from $10 \mathrm{nM}-100 \mu \mathrm{M}$, as shown in Fig. 1b

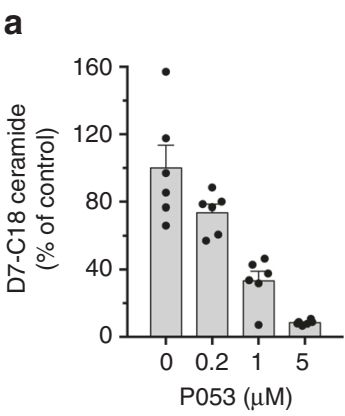

d

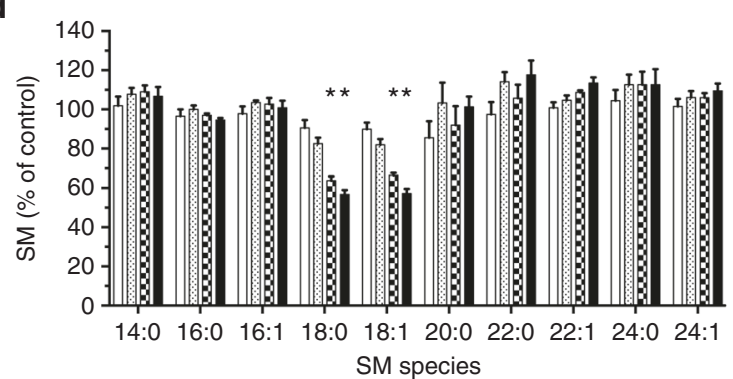

b
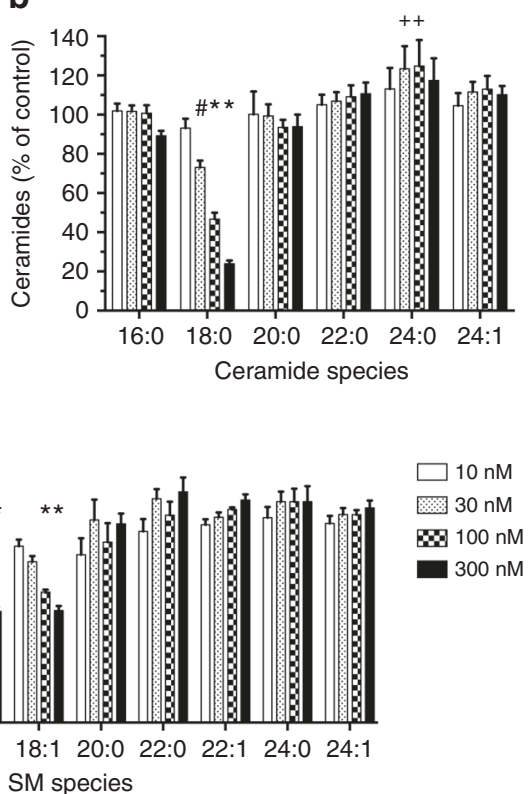

c

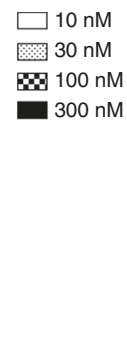

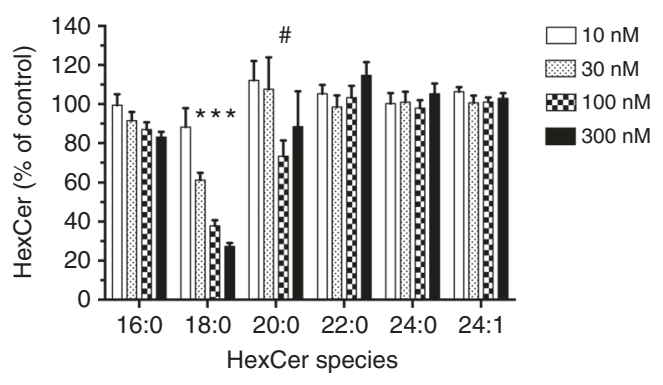

e

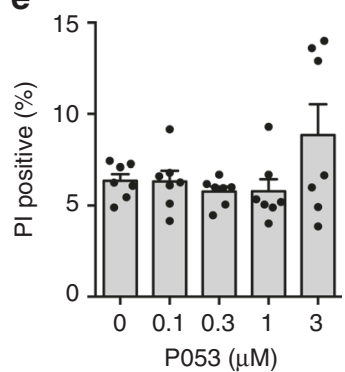

Fig. 2 P053 selectively reduces C18 sphingolipids in cultured cells. a Formation of deuterated ceramide from deuterated (D7) dihydrosphingosine in cortical neuron cultures pre-treated for $2 \mathrm{~h}$ with P053. b-d Endogenous ceramide (b), HexCer (c), and SM (d) levels in HEK293 cells treated for $24 \mathrm{~h}$ with P053 at concentrations indicated on the graphs. Lipid levels are expressed as a percentage of vehicle control levels. Absolute lipid levels are shown in Supplementary Figure 1, with raw data for these images provided in Supplementary Data File 1. e Percentage of non-viable HEK293 cells determined by propidium iodide (PI) staining and flow cytometry, following a $72 \mathrm{~h}$ treatment with P053. All graphs show combined data from two independent experiments, each with 3 (a) or 4 (b-d) separate cell treatments, mean \pm SEM. Statistical significance in (b-d) was determined by $t$-tests adjusted for multiple comparisons, comparing all lipids (22 lipids tested in total) at each concentration to the control group; ${ }^{+} P<0.05$; ${ }^{\#} P<0.01 ;{ }^{\star} P<0.001$

a function of substrate concentration is sigmoidal, particularly for the C18:0-CoA substrate, indicative of a cooperative binding model. P053 reduces maximal reaction rate $\left(V_{\max }\right)$ without notably affecting substrate affinity $\left(K_{\text {half }}\right)$ (Fig. 1c, d), indicating that it is a non-competitive inhibitor.

In a live-cell ceramide synthase assay ${ }^{34}$ using cortical neuron cultures, a two hour pre-treatment with $\mathrm{P} 053$ resulted in dosedependent inhibition of de novo C18:0 ceramide synthesis from deuterated dihydrosphingosine (Fig. 2a), confirming that the drug is cell permeable and inhibits CerS1 activity in living cells. We next tested the potency and specificity of our inhibitor in reducing endogenous ceramides. Most cell lines produce very little C18 ceramide. HEK293 cells produce more C18 ceramide than other immortalised cell lines that we tested, and we therefore quantified endogenous ceramides in HEK293 cells treated for 24 $\mathrm{h}$ with P053. C18:0 ceramide was reduced by 53\% with $100 \mathrm{nM}$ P053 (Fig. 2b, Supplementary Figure 1 and Supplementary Data File 1). No other forms of ceramide were reduced by P053 treatment, but a minor increase in C24:0 ceramide was observed (Fig. 2b). In addition to C18 ceramide, the compound selectively reduced C18 HexCer (Fig. 2c) and SM (Fig. 2d), which are both derived from C18 ceramide. P053 had no effect on HEK293 cell viability at or below $1 \mu \mathrm{M}$ (Fig. 2e).
FTY720 has been reported to inhibit sphingosine kinase 1 in the low micromolar range ${ }^{35}$. P053 did not inhibit recombinant human sphingosine kinase 1 or 2 to any extent at $10 \mu \mathrm{M}$, whereas $10 \mu \mathrm{M}$ FTY720 produced a $60 \%$ reduction in sphingosine kinase 1 activity (Supplementary Figure 2).

P053 selectively targets CerS1 in vivo. To investigate the in vivo efficacy of P053, bioavailability was tested by administering a single $5 \mathrm{mg} / \mathrm{kg}$ dose by oral gavage to mice (Fig. 3a). A maximal plasma concentration of $20 \mathrm{nM}$ was achieved $4 \mathrm{~h}$ after administration, with a plasma half-life of $28 \mathrm{~h}$. Expression profiling confirmed previous literature ${ }^{18}$ and showed that CerS1 is highly expressed in brain and SkM, with minimal or no expression in other tissues, including adipose tissue (Fig. 3b). In a pilot study, 7 days administration of $\mathrm{P} 053$ at $5 \mathrm{mg} / \mathrm{kg} /$ day reduced $\mathrm{C} 18$ ceramide levels in SkM by $31 \%$, whereas $1 \mathrm{mg} / \mathrm{kg} /$ day had no effect. To fully characterise the effects of the compound on the lipidome, we administered $5 \mathrm{mg} / \mathrm{kg}$ P053 daily for 4-6 weeks to mice fed either normal chow or a HFD. Of 302 individual lipid species manually verified following lipidomic profiling of SkM, only 18:1/ 18:0 and 18:2/18:0 ceramide were significantly reduced at $P$ $<0.01$, after adjusting for multiple comparisons (Fig. $3 \mathrm{c}-\mathrm{e}$, and 

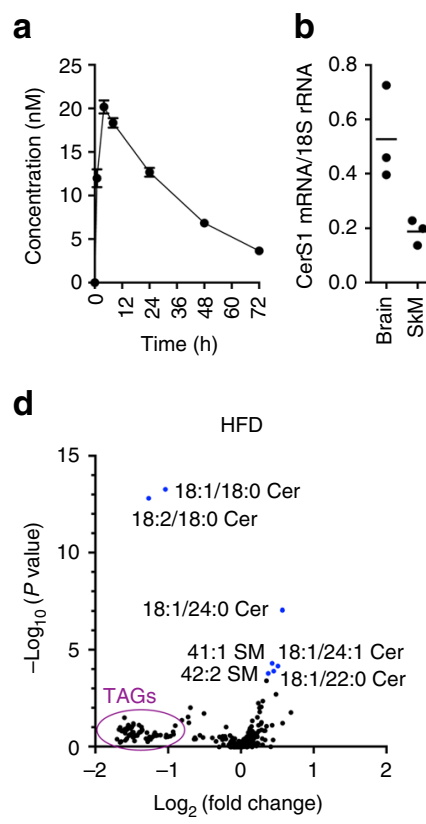

g

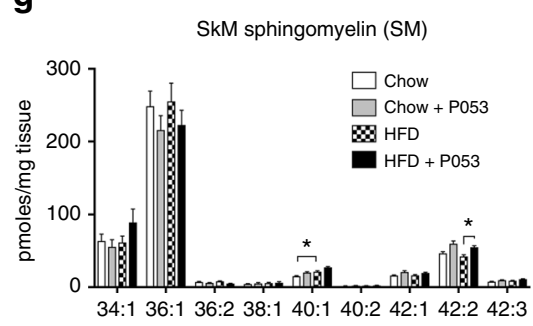

e
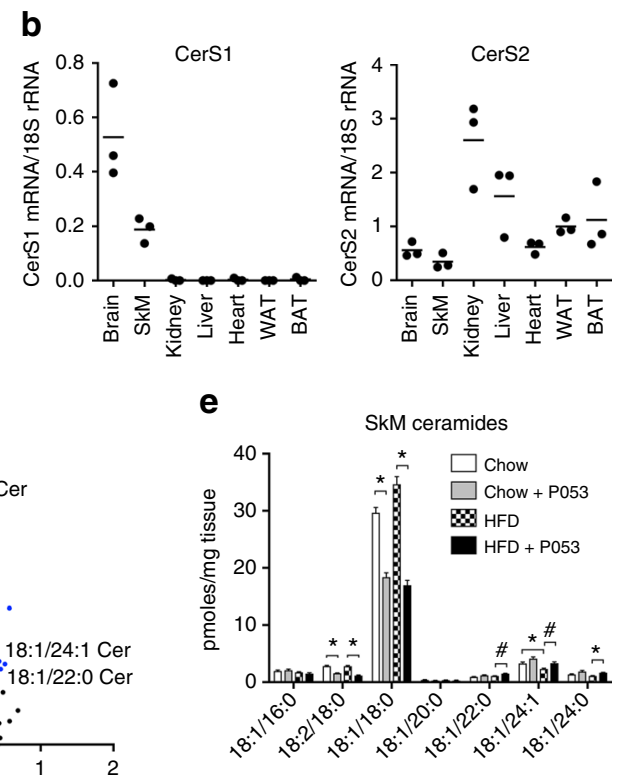

$\mathbf{h}$

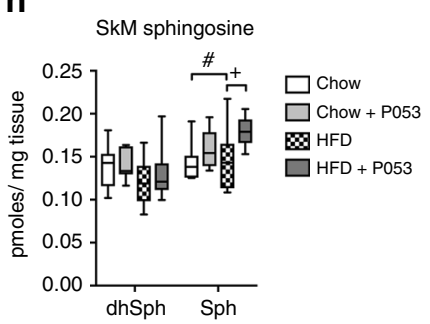

k

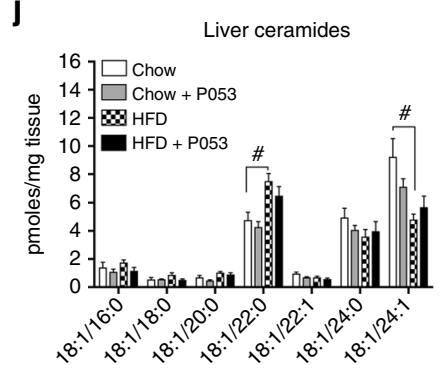

k

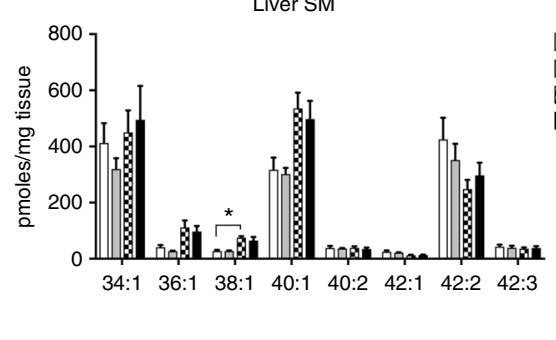

I

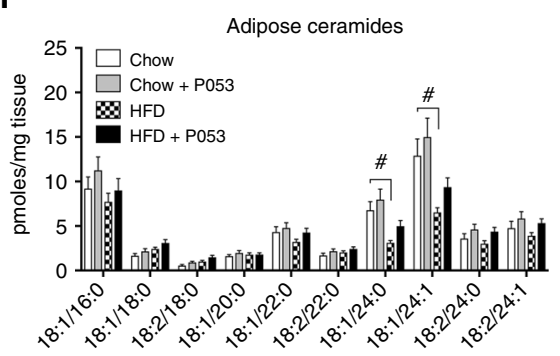

m

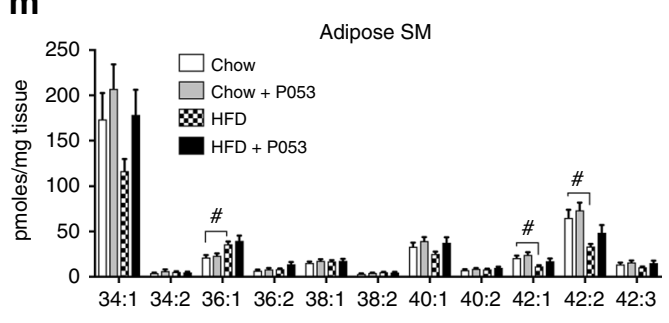

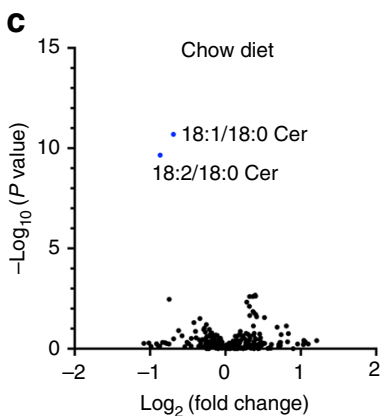

$\mathbf{f}$

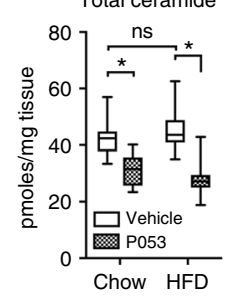

i

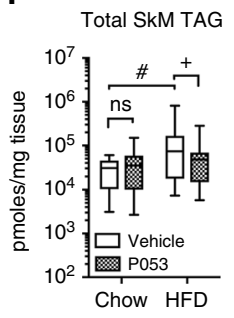

Supplementary Data File 2). As C18 is the dominant ceramide in SkM, P053 treatment reduced total ceramide content in this organ (Fig. 3f; $P=0.73$ for effect of diet, $P<0.001$ for effect of P053 by 2-way ANOVA). Very long chain ceramides (C22:0, C24:0 and C24:1) were significantly increased by P053 treatment in the HFD group (Fig. 3d, e), as was 42:2 SM, which is assumed to be the 18:1/24:1 (C24:1) form (Fig. 3g). Mean levels of 36:1 SM, which is derived from C18:0 ceramide, were 13\% lower in P053treated compared to vehicle-treated mice on both diets (Fig. 3g), however this effect was not statistically significant. HexCer content was not significantly affected by P053 treatment (Supplementary Data File 2). The increase in C24 ceramides was not associated with increased C24 ceramide synthase activity (Supplementary Figure 3), and may therefore be a consequence of increased sphingoid base substrate availability due to the reduction in CerS1 activity. In accordance with this model, sphingosine levels were increased $22 \%$ as a result of CerS1 inhibition with P053 in mice fed a HFD (Fig. $3 \mathrm{~h} ; P=0.01$ ), and $11 \%$ in mice fed a chow diet (not significant). Dihydrosphingosine levels were not notably affected by P053 treatment (Fig. 3h). 
Fig. 3 CerS1 inhibition selectively reduces C18 ceramide in SkM. a Plasma P053 concentration following a single $5 \mathrm{mg} / \mathrm{kg}$ oral dose $(n=5 \mathrm{mice} ;$ mean \pm SEM). b CerS1 mRNA expression was determined in a panel of mouse tissues by quantitative PCR ( $n=3$ mice; horizontal bar shows mean). Levels are normalised to $18 \mathrm{~S}$ rRNA. WAT epididymal white adipose tissue, BAT brown adipose tissue. Results for CerS2 are also shown, to demonstrate the presence of RNA in samples from tissues lacking CerS1 expression. c, d Volcano plots showing $P$ value plotted against fold change for each of 302 lipids in SkM of P053-treated relative to vehicle-treated mice. $\mathbf{c}$ Chow diet, d HFD, $n=18-20$ per group. Lipids significantly altered in P053 vs vehicle are shown in blue and labelled by name. e Levels of individual ceramides, $\mathbf{f}$ total ceramide, $\mathbf{g}$ individual SM species, $\mathbf{h}$ dihydrosphingosine (dhSph) and sphingosine (Sph), and i total TAG, in SkM of mice fed chow or HFD with vehicle or $5 \mathrm{mg} / \mathrm{kg}$ P053 for 4-6 weeks ( $n=18-20$ per group; $n=8-10$ per group for dhSph and Sph). $\mathbf{j}$ - $\mathbf{m}$ Liver ceramides (j), liver SM species (k), epididymal adipose ceramides (I), and epididymal adipose SM species ( $\mathbf{m}) ; n=10$ per group. Bar graphs show mean $\pm \mathrm{SEM} ;{ }^{\#} P<0.01 ;{ }^{*} P<0.001$, as determined by two-tailed $t$-tests adjusted for multiple comparisons ( $P$ values are after adjusting for multiple comparisons). Box and whisker plots show full data range with 25th-75th percentile boxed, and horizontal bar marking the median. Results in (f), (h), and (i) were analysed by two-way ANOVA, with Fisher's exact post-test to compare individual groups $\left(+, P<0.05 ;{ }^{\#} P<0.01 ;{ }^{\star} P<0.001\right)$. Raw data for $\mathbf{e}, \mathbf{g}, \mathbf{j}, \mathbf{k}, \mathbf{I}$ and $\mathbf{m}$ is provided in Supplementary Data File 1

Table 2 Correlations between SkM ceramides and body fat

\begin{tabular}{|llllll} 
& \multicolumn{3}{l}{ Body fat (\%) } & & \multicolumn{2}{l}{ WAT weight } \\
\cline { 2 - 3 } \cline { 5 - 6 } Ceramide & $\boldsymbol{r}$ & $\mathbf{P}$ & & $\boldsymbol{r}$ & $\mathbf{P}$ \\
\hline Total & 0.010 & 0.54 & & 0.138 & 0.40 \\
18:1/16:0 & -0.156 & 0.34 & & -0.164 & 0.31 \\
18:1/18:0 & $\mathbf{0 . 3 6 7}$ & $\mathbf{0 . 0 2 0}$ & $\mathbf{0 . 3 9 3}$ & $\mathbf{0 . 0 1 2}$ \\
18:1/20:0 & -0.197 & 0.22 & & -0.030 & 0.85 \\
18:1/22:0 & 0.209 & 0.196 & & 0.267 & 0.096 \\
18:1/24:0 & $-\mathbf{0 . 5 2 4}$ & $\mathbf{0 . 0 0 0 5}$ & & $\mathbf{- 0 . 4 6 4}$ & $\mathbf{0 . 0 0 2 5}$ \\
18:1/24:1 & $-\mathbf{0 . 5 3 5 3}$ & $\mathbf{0 . 0 0 0 4}$ & $\mathbf{- 0 . 4 2 8}$ & $\mathbf{0 . 0 0 5 8}$ \\
\hline
\end{tabular}

Spearman correlation co-efficients $(r)$ and $P$ values are shown. Significant associations are in bold. Body fat $\%$ was determined by EchoMRI, whilst WAT weight is the combined weight of inguinal and epididymal adipose pads. Mice from both chow and HFD groups were used for this analysis ( $n=38$ mice). Mice treated with P053 were not included in this analysis, due to the confounding effect of P053 on muscle ceramides

This untargeted lipidomic data using quadriceps was supported by targeted analysis of ceramide, SM and HexCer in gastrocnemius muscle, which showed a significant increase in $\mathrm{C} 18$ ceramide content in the HFD compared to the chow control group, and significant reductions in C18 ceramide (i.e., 18:1/18:0), C18 dihydroceramide (i.e., 18:0/18:0), and 18:2/18:0 ceramide with P053 treatment (Supplementary Figure 4).

P053 treatment did not affect levels of common phospholipids from the phosphatidylcholine, phosphatidylethanolamine, phosphatidylserine, and phosphatidylinositol families (Supplementary Data File 2). We noted that the levels of most triacylglycerol (TAG) species were reduced by more than $50 \%$ in SkM of the HFD + P053 compared to HFD + vehicle group (Fig. 3d). Total SkM TAG content was increased five-fold in mice on a HFD compared to a chow diet (Fig. 3i; $P=0.01$ for main effect of diet, $P=0.15$ for effect of P053 by two-way ANOVA), and was $60 \%$ lower in the HFD + P053 group compared to the HFD vehicle group $(P=0.021)$. P053 treatment did not affect SkM TAG levels in mice fed normal chow (Fig. 3i). TAGs are synthesized directly from diacylglycerol (DG). DG levels were unaffected by P053 treatment (Supplementary Figure 5), suggesting that P053 does not directly inhibit TAG synthesis from DG.

Of 265 lipids measured in liver, none was significantly affected by P053 treatment in mice fed either chow or HFD (Supplementary Data File 2), despite the fact that there is substantial uptake of P053 in the liver (Supplementary Figure 6). There were 40 lipids significantly affected by diet $(P<0.01$ after adjusting for multiple comparisons), including $\mathrm{C} 22: 0$ and $\mathrm{C} 24: 1$ ceramide (Fig. 3j), in line with previous results ${ }^{20}$, and 38:1 SM (Fig. 3k). Similarly, P053 did not significantly impact on levels of C18 ceramide or SM, nor other ceramide or SM species, in adipose tissue, although there were a number of diet-induced changes (Fig. 31, m). The lack of effect of P053 in liver and adipose tissue is likely a reflection of the very low levels of CerS1 in these tissues
(Fig. 3b). Although CerS1 is highly expressed in brain (Fig. 3b), P053 did not affect C18 ceramide or SM (particularly SM 36:1) levels in cerebellum (Supplementary Figure 7). This may be a consequence of three-fold lower levels of the compound in brain tissue compared to SkM (Supplementary Figure 6).

The action of FTY720 as an immunosuppressant is dependent on its phosphorylation ${ }^{36,37}$. AAL(S), from which P053 is derived, is a non-phosphorylatable FTY720 analogue ${ }^{37}$. In cultured HEK293 cells incubated with FTY720, FTY720-phosphate was clearly detected, whereas the phosphate of P053 was not detected in either cultured cells or plasma of mice administered the drug, indicating that like the parent compound $\mathrm{AAL}(\mathrm{S}), \mathrm{P} 053$ is nonphosphorylatable (Supplementary Figure 8).

CerS1 inhibition prevents fat deposition but not insulin resistance induced by a HFD. A recent study showed that the $\mathrm{C} 18$ ceramide content of SkM is positively correlated with visceral fat mass in humans ${ }^{22}$. In vehicle-treated mice in the current study, C18 ceramide levels in SkM were positively correlated, and C24 ceramides were inversely correlated, with body fat (Table 2). These correlations are indicative of a relationship between the ceramide content of SkM and whole-body adiposity. In agreement with this hypothesis, P053 treatment significantly reduced whole-body fat mass and the weight of individual white adipose depots in mice fed a HFD (Fig. 4a-e). Mean fat pad weights were $0.52 \mathrm{~g}$ (epididymal) and $0.27 \mathrm{~g}$ (inguinal) higher in mice fed a HFD compared to a chow diet. This gain in fat mass was almost halved to $0.29 \mathrm{~g}$ (epididymal) and $0.15 \mathrm{~g}$ (inguinal) with P053 treatment. This reduced fat mass was not due to any effect of P053 on food intake (Supplementary Figure 9). There is a close association between excess adiposity and insulin resistance ${ }^{38}$ and as expected HFD-fed mice displayed elevated fasting insulin (Fig. 4f) and became glucose intolerant (Fig. 4g) due to impaired glucose disposal during the glucose tolerance test (Supplementary Figure 10). Hyperinsulinemic/euglycemic clamps revealed that fat-fed animals displayed a lower glucose infusion rate (indicating whole-body insulin resistance) (Fig. 4h), impaired peripheral glucose disposal (Fig. 4i) and reduced insulin-stimulated glucose uptake in SkM (quadriceps and soleus; Fig. 4j, k). Despite its marked effects on adiposity and SkM ceramide, P053 treatment had no impact on any of these measures of glucose homoeostasis and insulin action (Fig. 4f-k).

CerS1 inhibition primes SkM to oxidise fatty acids. In simple terms, lipid accumulation in tissues is determined by the balance between oxidation and storage. Previous studies have reported that the lipotoxic effects of $\mathrm{C} 16$ ceramide are partly due to inhibition of fatty acid $\beta$-oxidation in liver and adipose tissue ${ }^{9,10}$. Muscle homogenates from chow and HFD-fed mice treated with P053 displayed increased oxidation of ${ }^{14} \mathrm{C}$-palmitate (Fig. 5a), suggesting that enhanced lipid oxidation may underlie the reduced lipid accretion in response to P053. To more directly 
a

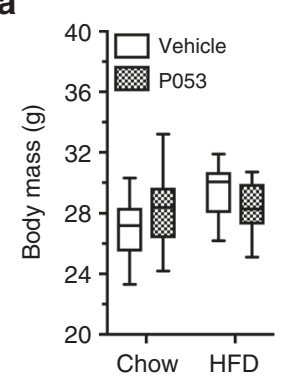

Drug: ns

Diet: $P=0.003$

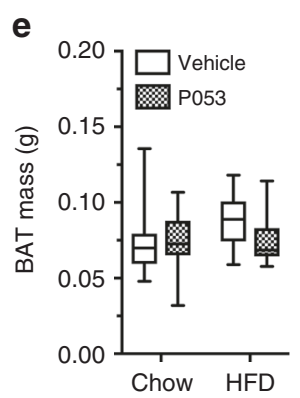

Drug: ns

Diet: $P=0.04$

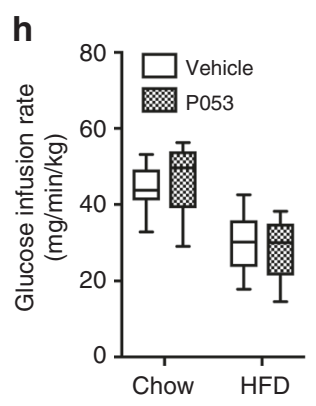

Drug: ns

Diet: $P<0.001$

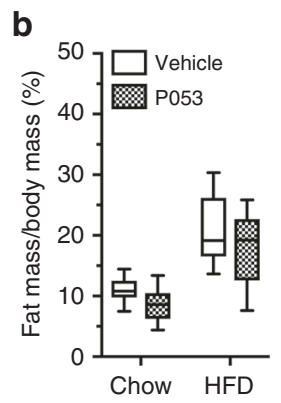

Drug: $P=0.008$

Diet: $P<0.001$

f

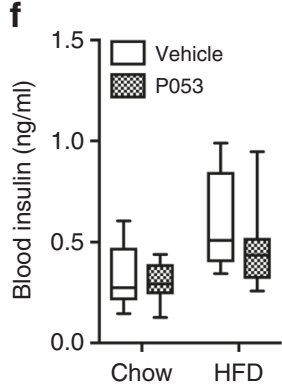

Drug: ns

Diet: $P=0.001$

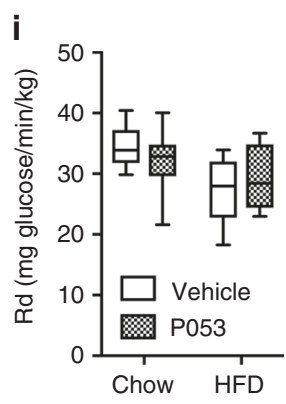

Drug: ns

Diet: $P=0.01$

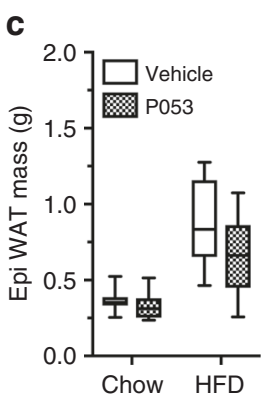

Drug: $P=0.003$

Diet: $P<0.001$ d

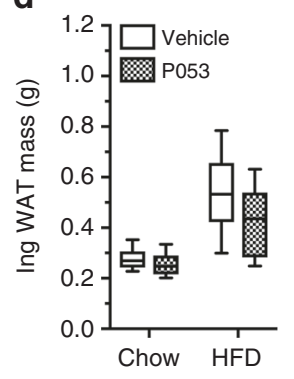

Drug: $P=0.002$

Diet: $P<0.001$

g

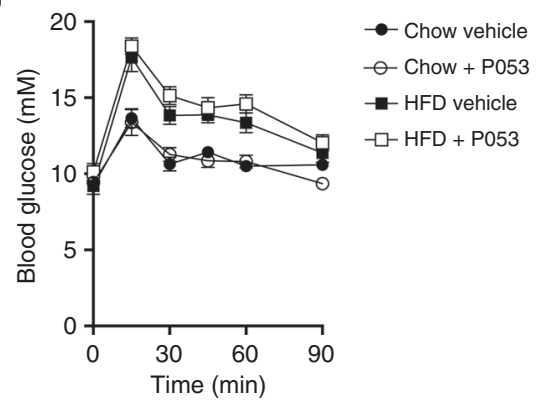

Drug (iAUC): ns

Diet (iAUC): $P<0.001$

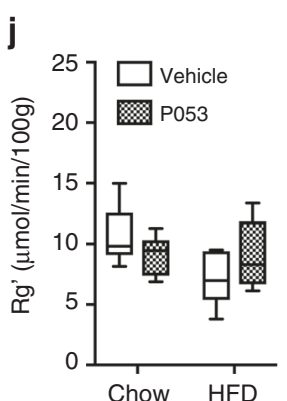

Drug: ns

Diet: $P=0.037$

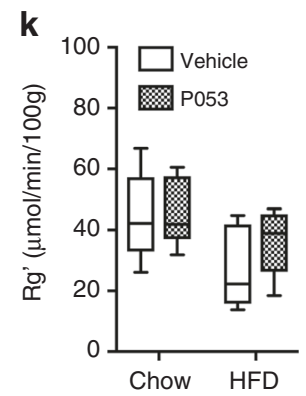

Drug: ns

Diet: $P=0.009$

Fig. 4 CerS1 inhibition impedes fat accumulation but not insulin resistance in mice fed a HFD. a Total body mass, b fat mass as a \% of body mass determined by EchoMRI, c epididymal white adipose tissue (WAT) mass, $\mathbf{d}$ inguinal WAT mass, and e brown adipose tissue (BAT) mass, in mice fed chow or HFD with vehicle or $5 \mathrm{mg} / \mathrm{kg}$ P053 for 4-6 weeks ( $n=20$ per group). f Fasting blood insulin and $\mathbf{g}$ blood glucose following an oral glucose load in mice fed chow or HFD with vehicle or $5 \mathrm{mg} / \mathrm{kg}$ P053 ( $n=10$ per group; mean \pm SEM). h Glucose infusion rate, $\mathbf{i}$ rate of glucose disposal from the circulation $(\mathrm{Rd})$, and $\mathbf{j}$, $\mathbf{k}$ rate of glucose uptake $\left(\mathrm{Rg}^{\prime}\right)$ into quadriceps $(\mathbf{j})$ and soleus $(\mathbf{k})$ muscles, as determined in hyperinsulinemic-euglycemic clamps $(n=6-9$ mice per group as detailed in the methods). Box and whisker plots (a-f) show full data range with 25th-75th percentile boxed, and horizontal bar marking the median. P-values showing the main effect of diet or drug, as determined by two-way ANOVA, are shown below each graph; ns not significant. ANOVA results for the incremental Area Under the Curve (iAUC) are given for ( $(\mathbf{g})$

differentiate between inhibition of TAG synthesis and enhanced lipid oxidation, we quantified TAG synthesis from ${ }^{14} \mathrm{C}$-palmitate, as well as production of $\mathrm{CO}_{2}$ and acid soluble metabolites (ASM) (i.e., $\beta$-oxidation intermediates), in soleus muscles from mice treated for 2 weeks with $\mathrm{P} 053$. Incorporation of ${ }^{14} \mathrm{C}$-palmitate into TAG during the $1 \mathrm{~h}$ incubation was unchanged (Fig. 5b), but oxidation of ${ }^{14} \mathrm{C}$-palmitate was significantly increased in soleus muscles from P053-treated mice (Fig. 5c). To assess if this was an acute effect of the compound, isolated soleus muscles were treated in vitro for $1.5 \mathrm{~h}$ with $\mathrm{P} 053$ before the assay. Palmitate oxidation was not affected by acute P053 treatment (Fig. 5d), suggesting that prolonged CerS1 inhibition is required to prime SkM to partition fatty acids to oxidative pathways over storage.

Fatty acid oxidation occurs in mitochondria and ceramides have been reported to directly influence mitochondrial function, as well as mitochondrial morphology and turnover $9,19,39$. Assessment of mitochondrial respiration in permeabilised muscle fibres revealed that the enhanced lipid oxidation in SkM in response to CerS1 inhibition was likely due to an overall increase in mitochondrial capacity, as there was a significant increase in respiratory activity in the presence of complex I and IV substrates, and a trend for an increase in complex II activity (Fig. 5e). Increased respiratory capacity was associated with significant up-regulation of genes encoding both mitochondrial-encoded (Co-2, Cytb, Atp6) and nuclear-encoded (Ndufb5, Atp5o, Cycs, Cox5b) respiratory complex subunits (Fig. 6a). Respiratory complexes were also upregulated at the protein level in SkM of P053-treated mice (Fig. 6b, c), accompanied by increased activity of the TCA cycle enzyme citrate synthase-a commonly used marker of mitochondrial content-and increased activity of the $\beta$-oxidation enzyme $\beta \mathrm{HAD}$ 
a

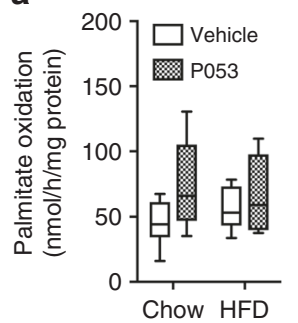

b

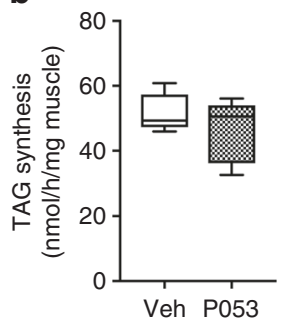

Drug: $P=0.01$

Diet: $\mathrm{ns}$
C

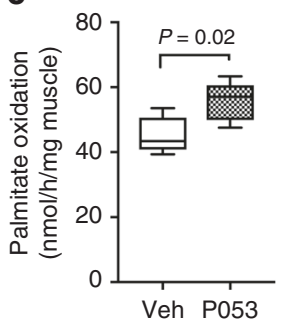

d

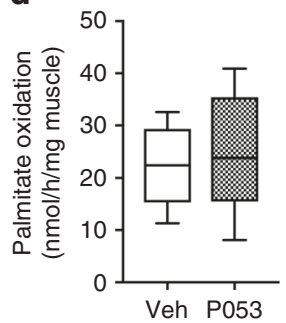

e

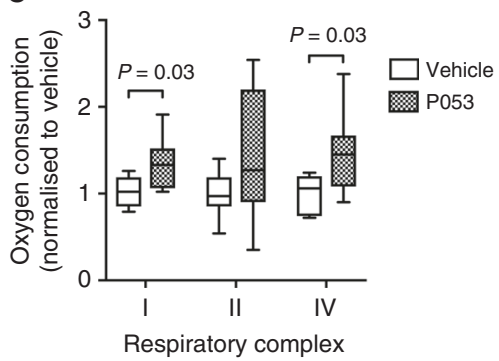

Fig. 5 CerS1 inhibition increases palmitate oxidation and mitochondrial respiratory capacity in SkM. a ${ }^{14} \mathrm{C}$-palmitate oxidation in SkM homogenates from mice treated for 6 weeks with P053 or vehicle $\left(n=10\right.$ mice). b ${ }^{14} \mathrm{C}$-palmitate incorporation into TAG, and $\mathbf{c}{ }^{14} \mathrm{C}$-palmitate oxidation, in isolated soleus muscles taken from mice treated for two weeks with $5 \mathrm{mg} / \mathrm{kg}$ P053 or vehicle control ( $n=5$ mice). Results show nmoles ${ }^{14} \mathrm{C}$-palmitate converted to $\mathbf{b}$ TAG or $\mathbf{c} \mathrm{CO}_{2}+$ acid soluble metabolites. d Palmitate oxidation in soleus muscle strips pre-treated for $1.5 \mathrm{~h}$ in vitro with $1 \mu \mathrm{M}$ P053 or vehicle control $(n=5$ mice). e ADP-stimulated (State 3 ) respiratory complex activities measured in permeabilised extensor digitorum longus muscle fibres of mice treated for three weeks with $5 \mathrm{mg} / \mathrm{kg}$ P053 or vehicle control ( $n=7$ mice). Statistical significance in (a) was determined by two-way ANOVA (main effect of drug and diet reported below the graph), and in (b-e) by two-tailed $t$-tests (results where $P<0.05$ are indicated on the graph)

$(P=0.06)$ (Fig. 6d). This effect was specific to muscle, with no increase in mitochondrial markers in liver (Fig. $7 \mathrm{a}-\mathrm{c}$ ), where CerS1 and C18:0 ceramide are low, and P053 had no significant effect on lipid levels.

Increased transcription of respiratory complex subunits suggested that P053 enhances mitochondrial biogenesis. Consistent with this, P053 treatment significantly increased protein expression of Pgc-1a, the master regulator of mitochondrial biogenesis $^{40}$ (Fig. 6e) and elevated mitochondrial DNA content (Fig. 6f; $P=0.06$ for main effect of P053 in 2-way ANOVA; $P=$ 0.007 for post-test comparing HFD vehicle to HFD + P053). The expression of transcriptional regulators of mitochondrial biogenesis Gabpla (Nuclear respiratory factor 2) ${ }^{41}$ and Nfe2l2 (nuclear factor (erythroid-derived 2)-like 2) ${ }^{42}$ was also significantly increased by $\mathrm{P} 053$ treatment (Fig. 6g). AMP-activated protein kinase (AMPK) is an important regulator of mitochondrial biogenesis in muscle ${ }^{43}$ whose activity is influenced by intracellular ceramide levels ${ }^{44}$. P053 treatment had no effect on phosphorylation of AMPK or its downstream substrate acetylCoA carboxylase (ACC) (Supplementary Figure 11), suggesting that this pathway is not involved in the enhanced mitochondrial function induced by CerS1 inhibition.

\section{Discussion}

There is a strong body of evidence indicating that different forms of ceramide, synthesized by different CerS isoforms, regulate distinct physiological processes ${ }^{1,8}$. However, research on the role of specific CerS isoforms is hampered by the absence of isoformselective CerS inhibitors. Researchers seeking to pharmacologically inhibit ceramide synthesis in vivo have generally used myriocin ${ }^{45-47}$, which inhibits serine palmitoyltransferase, the rate limiting initial step in the biosynthesis of all sphingolipids. This report describes the first potent and selective inhibitor of any CerS isoform, facilitating the discovery of a physiological role for CerS1 in the regulation of mitochondrial function and fatty acid metabolism. P053 exhibits strong selectivity for CerS1 over other CerS isoforms, potently and very specifically reducing C18 ceramide levels in cultured cells and mouse SkM. CerS1 inhibition with P053 was also successfully dissected from non-specific proapoptotic properties of sphingoid base analogues $27,48,49$, as the compound inhibited C18 ceramide synthesis at concentrations at least one order of magnitude lower than those required to promote apoptosis in HEK293 cells. Interestingly, the mode of inhibition was non-competitive with respect to either the sphingosine or C18 fatty acyl-CoA substrate, suggesting that P053 may bind an allosteric site, possibly a lipid binding site on the enzyme. In the absence of structural data for the ceramide synthase family, or sitable homology models, we are unable to fully characterise the mechanism of inhibition. Both CerS1 and CerS4 activities were assayed using C18:0 fatty acid substrate, indicating that inhibition by $\mathrm{P} 053$ is specific to the CerS1 isoform and not the specific fatty acid substrate used to measure enzyme activity.

Our report provides the first pharmacological evidence that endogenous CerS1 is indeed highly selective for C18 fatty acid substrates, as treatment of cells or mice with P053 resulted in selective reduction of $\mathrm{C} 18$ ceramide. These findings support experiments in which CerS1 has been overexpressed ${ }^{15}$, silenced ${ }^{50}$, or knocked out ${ }^{14}$. We observed small but statistically significant increases in C24 ceramides in SkM of mice following inhibition of CerS1. This was not associated with increased C24 ceramide synthase activity and is therefore most likely a consequence of increased availability of sphingoid base substrates for CerS2catalysed C24 ceramide synthesis in the absence of CerS1 activity. This is consistent with two distinct genetic mouse models of CerS1 deficiency ${ }^{14,51}$, and supported by our observation that sphingosine levels were only modestly increased, and dihydrosphingosine levels were not increased, in SkM of P053-treated mice. C22 and C24 ceramide levels are an order of magnitude higher than free sphingosine in SkM, so re-routing of sphingoid base substrates into these ceramides would prevent significant increases in sphingosine upon CerS1 inhibition. In both HEK293 cells and mouse SkM the reduction in C18 forms of SM were much less prominent than the changes in C18 ceramides. These findings indicate that either the turnover rate for SM is slower than ceramide, or that steady state C18 SM levels are preferentially maintained at the expense of $\mathrm{C} 18$ ceramide.

P053 treatment significantly affected ceramide content, particularly C18 ceramide, in SkM, but not liver or adipose tissue. This tissue-specific pattern may simply be a reflection of the substantial differences in CerS1 expression/activity between SkM and other organs. Although CerS1 is highly specific for C18 ceramide synthesis, other CerS isoforms, particularly CerS4 and 5, are capable of catalysing C18 ceramide synthesis ${ }^{12,16}$. However, it is also possible that lower abundance ceramide species may be primarily obtained from the circulation and not through endogenous synthesis in some organs. In support of this notion, shortterm infusion of LDL containing C24:0 ceramides in mice was shown to alter membrane C24:0 ceramide content in $\mathrm{SkM}^{52}$. Surprisingly, there was no effect of P053 on ceramide levels in the 
a

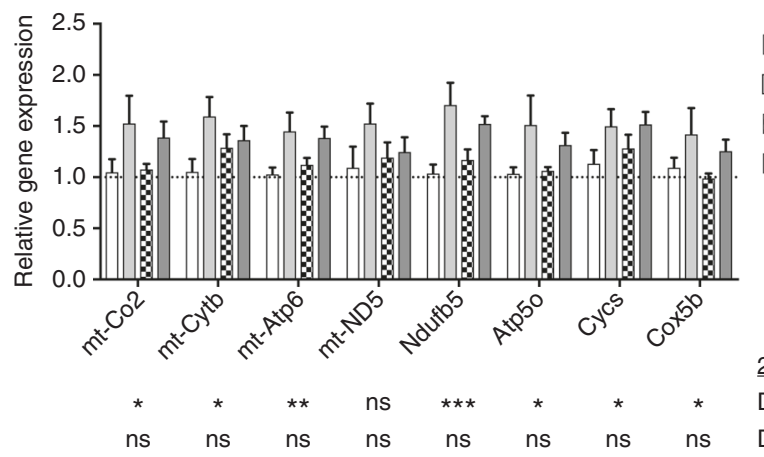

d

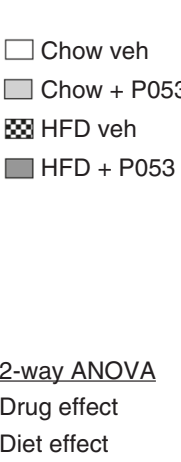

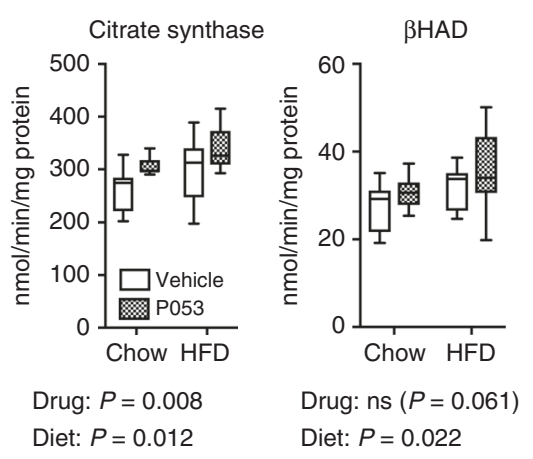

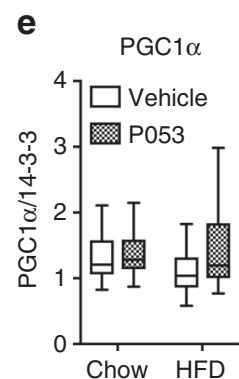

Drug: $P=0.032$

Diet: ns f

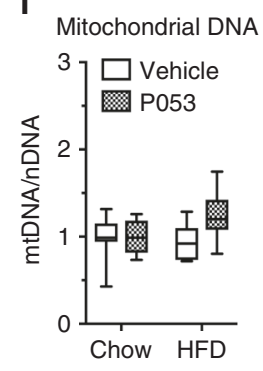

Drug: ns $(P=0.064)$

Diet: ns

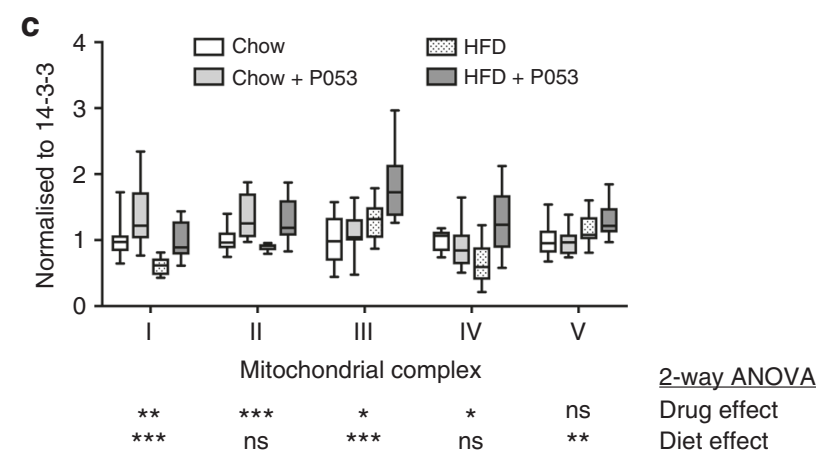

g

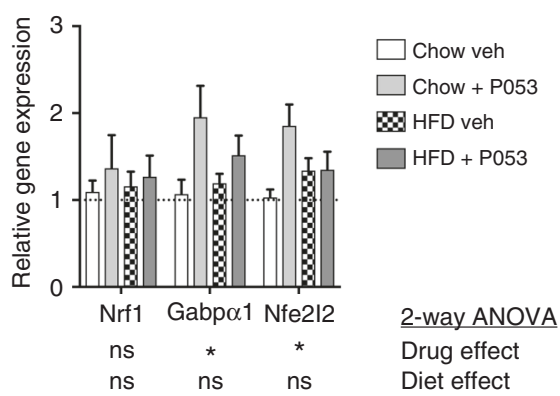

Fig. 6 CerS1 inhibition increases mitochondrial markers in SkM. a Levels of mitochondrially (mt)- and nuclear-encoded respiratory complex subunits in SkM, as determined by real-time PCR; $n=9$ for chow diet groups; $n=10$ for HFD groups. b Western blots of respiratory complex subunits in SkM. c Densitometry for respiratory complex subunits relative to 14-3-3 protein. $\mathbf{d}$ Citrate synthase and $\beta$-hydroxyacyl coenzyme A dehydrogenase ( $\beta \mathrm{HAD}$ ) activity in SkM. b-d, $n=10$ mice for all groups except the chow + P053 group, for which $n=8$. e Western blot of PGC-1 $\alpha$ protein levels with densitometry normalised to 14-3-3 protein, $n=18-20$ mice per group. $\mathbf{f}$ Mitochondrial DNA (mtDNA) content, normalised to nuclear DNA (nDNA) and expressed relative to the mean of the control group; $n=10$ mice for all groups except the chow + P053 group, for which $n=8$. $\mathbf{g}$ Gene expression levels for regulators of mitochondrial biogenesis and function, as determined by real-time PCR; $n=8$ for chow diet groups; $n=10$ for HFD groups. $\mathbf{a}$, $\mathbf{g}$ show mean \pm SEM. Box and whisker plots show full data range with 25th-75th percentile boxed, and horizontal bar marking the median. Statistical significance was determined by two-way ANOVA, with the main effect of the drug or diet shown beneath each result; ${ }^{\star} P<0.05$; ${ }^{\star \star} P<0.01$; ${ }^{\star \star \star} P<0.001$. Raw data for panels $\mathbf{a}$ and $\mathbf{g}$ is provided in Supplementary Data File 1

brain, despite high CerS1 expression levels. This appeared to be due to low uptake and/or retention of P053 in this organ (Supplementary Figure 6), but could also indicate a lower rate of sphingolipid turnover in brain compared to SkM. Genetic ablation of CerS1 causes neurodegeneration and cerebellar atrophy during development ${ }^{14,51}$, and the lack of an effect of P053 on brain ceramides indicates that treatment with P053 is unlikely to cause neuronal atrophy.

Our CerS1 inhibitor empowered us to dissect the role for SkM C18 ceramide in fat metabolism from its proposed role in insulin sensitivity. C18 ceramide levels were $20-30 \%$ higher in SkM of mice fed a high fat compared to chow diet. CerS1 inhibition with P053 significantly impeded fat deposition in mice fed a HFD and reduced the C18 ceramide level in SkM to well below that of control mice, but did not have any impact on glucose disposal, nor insulin-stimulated glucose uptake into SkM. Blocking total sphingolipid synthesis with myriocin has been shown to protect against insulin resistance and hepatic steatosis in rodents ${ }^{45-47}$, as has genetic ablation of Cers5 and CerS6 in liver and adipose tissue $^{10}$. It is therefore possible that CerS isoforms that are more highly expressed in liver and adipose tissue, specifically CerS2, CerS5, and CerS6, play a much more significant role than CerS1 in regulating glucose homoeostasis and insulin action. This, inturn, suggests either that the associations between C18 ceramide and insulin resistance in humans ${ }^{11,22,23}$ are correlative, but not causal; or that $\mathrm{C} 18$ ceramide in muscle is a more significant 
a

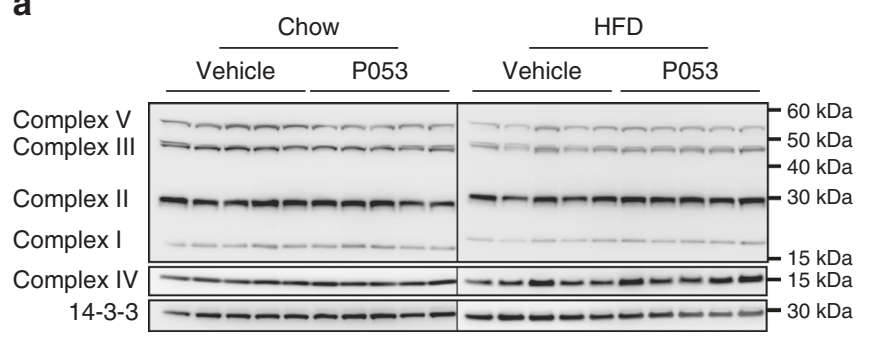

b

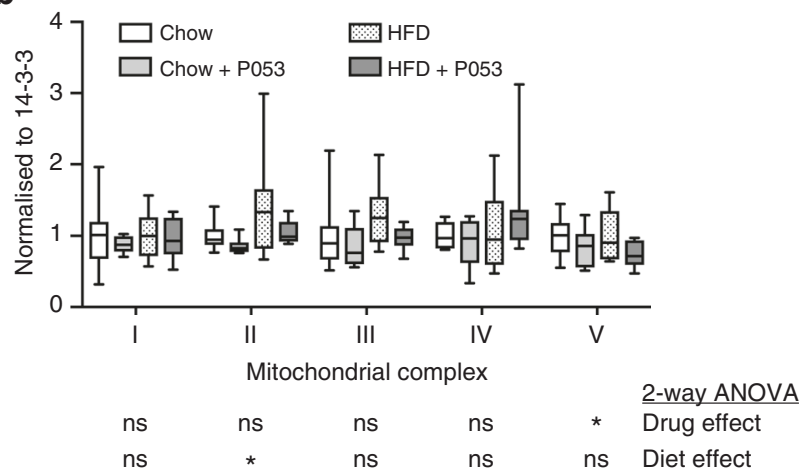

C

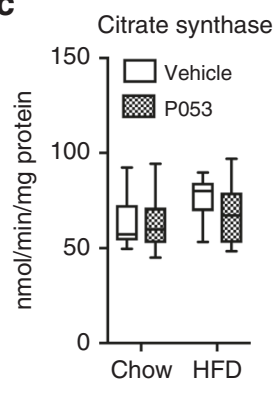

Drug: ns

Diet: $P=0.046$

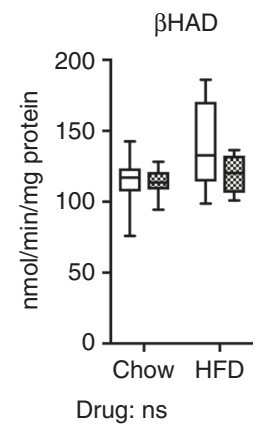

Diet: $P=0.014$

Fig. 7 CerS1 inhibition does not affect mitochondrial markers in liver. a Western blots of respiratory complex subunits, $\mathbf{b}$ densitometry for respiratory complex subunits relative to $14-3-3$ protein, and c Citrate synthase and $\beta \mathrm{HAD}$ activity in liver homogenates; $n=10$ mice for all groups. Box and whisker plots show full data range with 25th-75th percentile boxed, and horizontal bar marking the median. Statistical significance was determined by two-way ANOVA, with the main effect of the drug or diet shown beneath each result; ${ }^{\star} P<0.05$

contributor to insulin resistance in humans exposed to a mixed diet of fats and simple carbohydrates than to rodents on a defined HFD.

Our results highlight a new role for CerS1 as a key regulator of mitochondrial oxidative capacity, with chronic CerS1 inhibition priming SkM to metabolise fatty acids. Palmitate oxidation was increased in both isolated muscles and SkM homogenates of mice treated with P053, but not following acute exposure to the drug. The enhanced palmitate oxidation following CerS1 inhibition was associated with higher respiratory capacity, increased mitochondrial protein levels, and increased gene expression for respiratory complex subunits. The dependence of these effects on CerS1 was evident in the fact that P053 treatment affected mitochondrial markers in SkM but not liver, where CerS1 levels are very low. Given the substantial contribution of SkM to whole-body energy expenditure ${ }^{53}$, enhanced channeling of fatty acids into oxidative pathways over storage in muscle over the course of the study provides a rational explanation for the reduced fat deposition in P053-treated mice on a HFD. However, to the best of our knowledge, there are no prior studies demonstrating that specifically enhancing fat metabolism in SkM reduces adiposity in mice fed a HFD. In fact, previous studies have shown that genetically enhancing fatty acid oxidation in SkM, through deletion of acetyl-CoA carboxylase 2 or muscle-specific expression of carnitine palmitoyltransferase-1, did not reduce adiposity ${ }^{54-56}$. An important point of difference with our study is that increased fatty acid oxidation was coupled with elevated markers of mitochondrial content and activity, i.e., CerS1 inhibition appears to have increased overall mitochondrial capacity and not just altered fuel selection. The rate of palmitate oxidation in isolated $\mathrm{SkM}$ was directly comparable to its incorporation into TAG (Fig. 5). Over days to weeks the sustained increase in fatty acid oxidation with P053 may be sufficient to offset fat deposition and weight gain. Additional evidence using other approaches to boost mitochondrial content and fatty acid oxidation is required to further test this possibility.

The precise mechanism through which chronic CerS1 inhibition changes mitochondrial content and/or function requires further investigation. Our findings of elevated expression of PGC$1 \alpha$ and other important transcriptional regulators of mitochondrial content and function (Gabpla $\alpha^{41}$ and $\mathrm{Nfe} 212^{42}$ ) suggest enhanced mitochondrial biogenesis in response to depletion of C18 ceramide in muscle. Other studies have shown downregulation of genes regulating fatty acid metabolism in the absence of CerS $2^{57}$, associated with reduced $\beta$-oxidation of fatty acids ${ }^{9}$. These effects were attributed to elevation of C16 ceramide in the absence of very long chain ceramide synthesis. Similarly, loss of CerS2 was shown to reduce respiratory enzyme activities and increase mitochondrial oxidative stress, effects that were also attributed to elevated $\mathrm{C} 16$ ceramide $^{58}$. Our data indicates that C18 ceramide behaves similarly to $\mathrm{C} 16$ ceramide in suppressing respiratory enzyme levels and fatty acid $\beta$-oxidation. Another possible contributor to changes in mitochondrial content/function in response to P053 treatment is reduced mitophagy, since exogenous CerS1 expression and a mitochondrial-targeted analogue of $\mathrm{C} 18$ ceramide were both shown to promote mitophagy ${ }^{39}$. Ceramides have also been shown to induce mitochondrial fission in SkM cells, reducing their oxidative capacity ${ }^{19}$. Thus, another possibility is that CerS1 inhibition, by lowering the overall ceramide content of SkM, boosts respiratory capacity via inhibition of fission.

There are several lines of evidence in the literature indicating that ceramides regulate fat storage. Firstly, genetic ablation of the Drosophila CerS homologue Schlank results in the absence of fat pads $^{59}$. Secondly, the serine palmitoyltransferase inhibitor myriocin reduces adiposity and hepatic steatosis in rodents fed a $\mathrm{HFD}^{45-47}$. Our finding that CerS1 inhibition significantly impedes fat deposition is perhaps surprising given that CerS1 is not expressed to a significant extent in adipose tissue or liver. However, C18 ceramide in SkM was positively correlated with visceral fat mass, blood pressure, and liver fat in a recent study in humans ${ }^{23}$, and we identified a significant positive correlation between $\mathrm{C} 18$ ceramide in SkM and whole body fat mass in mice, as determined by two different methods: Echo MRI and weight of dissected fat pads (Table 2). Our experiments with P053 suggest that this is a causal relationship, as P053 significantly reduced C18 ceramide in SkM without affecting ceramide levels in liver and adipose tissue. We note that an even stronger inverse correlation of $\mathrm{C} 24$ ceramides with adipose tissue weight and \% body fat was observed. The inhibition of CerS1 may therefore reduce adiposity both directly by reducing C18 ceramide in SkM and indirectly through the associated increase in C24 ceramide. We cannot definitively rule out a direct effect of CerS1 inhibition on 
adipose tissue causing reduced adiposity, however, this seems unlikely given the absence of CerS1 in this tissue and the fact that $\mathrm{C} 18$ and $\mathrm{C} 24$ ceramide levels in adipose tissue were not affected by our inhibitor.

In summary, we have generated the first isoform-selective CerS inhibitor, specifically targeting CerS1 with nanomolar potency. Our results support a model in which CerS1 activity and C18 ceramide in SkM are not requisite for the development of insulin resistance in mice fed a HFD, but do play a very significant role in storage of dietary fats by acting as a brake on mitochondrial fatty acid oxidation. Our inhibitor will provide a valuable resource for researchers seeking to understand the functions of CerS1 in physiology and pathology, and the marked influence of P053 on whole-body and tissue-specific lipid accumulation further strengthens the notion that targeting ceramide synthesis may be a viable therapeutic option for treating obesity.

\begin{abstract}
Methods
Synthesis and chemical characterisation of G024 and P053 (2R,5S)-5-Isopropyl-3,6-dimethoxy-2-(4'-benzyloxyphenethyl)-2,5-dihydropyrazine. A solution of $n$-butyllithium in hexanes $(1.7 \mathrm{M}, 6.0 \mathrm{~mL}, 10.25 \mathrm{mmol})$ was added dropwise to a solution of freshly distilled (S)-Schöllkopf's reagent $(1.89 \mathrm{~g}, 10.26$ $\mathrm{mmol}$ ) in freshly distilled THF $(22 \mathrm{~mL})$ at $-78^{\circ} \mathrm{C}$ (dry ice/acetone). The solution was stirred at $-78^{\circ} \mathrm{C}$ for $15 \mathrm{~min}$, where it had turned dark yellow. A solution of 2(4'-benzyloxyphenyl)-1-iodoethane ${ }^{60}(3.50 \mathrm{~g}, 10.35 \mathrm{mmol})$ in freshly distilled THF $(21 \mathrm{~mL})$ at $-78^{\circ} \mathrm{C}$ was added dropwise. The solution was stirred for a further $30 \mathrm{~min}$ at $-78^{\circ} \mathrm{C}$ then allowed to slowly warm to $-15^{\circ} \mathrm{C}$ over $4 \mathrm{~h}$. The reaction mixture was quenched with saturated aqueous sodium bicarbonate solution and allowed to warm to room temperature. The THF was removed under reduced pressure and the residue extracted with dichloromethane $(\times 4)$. The organic extracts were combined and dried $\left(\mathrm{Na}_{2} \mathrm{SO}_{4}\right)$. The solvent was removed under reduced pressure and the crude material was purified by flash chromatography on silica gel, eluting with $3 \%$ ethyl acetate $n$-hexane, to afford the product as a clear colourless oil $(3.84 \mathrm{~g}$, quant $) .[\alpha]_{D}^{25.0^{\circ} \mathrm{C}}=-6\left(0.5, \mathrm{CHCl}_{3}\right) ;{ }^{1} \mathrm{H}$ NMR $\left(300 \mathrm{MHz} ; \mathrm{CDCl}_{3}\right) \delta 0.70$ $(\mathrm{d}, J=6.8 \mathrm{~Hz}, 3 \mathrm{H}), 1.06(\mathrm{~d}, J=6.8 \mathrm{~Hz}, 3 \mathrm{H}), 1.92-2.02(\mathrm{~m}, 1 \mathrm{H}), 2.07-2.19(\mathrm{~m}, 1 \mathrm{H})$, 2.22-2.32 (m, $1 \mathrm{H}), 2.48-2.64(\mathrm{~m}, 1 \mathrm{H}), 3.69(\mathrm{~s}, 3 \mathrm{H}), 3.70(\mathrm{~s}, 3 \mathrm{H}), 3.97(\mathrm{t}, J=3.4 \mathrm{~Hz}$, $1 \mathrm{H}), 4.02-4.07(\mathrm{~m}, 1 \mathrm{H}), 5.04(\mathrm{~s}, 2 \mathrm{H}), 6.89(\mathrm{dd}, J=2.1,4.7 \mathrm{~Hz}, 2 \mathrm{H}), 7.10-7.12(\mathrm{~m}$, 2H), 7.29-7.45 (m, 5H); ${ }^{13} \mathrm{C}$ NMR $\left(75 \mathrm{MHz} ; \mathrm{CDCl}_{3}\right) \delta 16.8,19.2,30.2,32.0,36.2$, 52.5, 55.1, 60.9, 70.2, 114.8, 127.6, 128.0, 128.7, 129.5, 134.7, 137.4, 157.1, 163.7, 163.9; IR ( $\mathrm{NaCl}$, neat) $1694 \mathrm{~cm}^{-1}$; HRMS (ESI-MS): $\mathrm{m} / z$ calcd for $\mathrm{C}_{24} \mathrm{H}_{31} \mathrm{~N}_{2} \mathrm{O}_{3}$ [M $+\mathrm{H}]^{+}$395.2334, found 395.2320 .
\end{abstract}

(2S,5S)-5-isopropyl-3,6-dimethoxy-2-(4'-benzyloxyphenethyl)-2-methyl-2,5dihydropyrazine. A solution of $n$-butyllithium in hexanes $(1.7 \mathrm{M}, 5.8 \mathrm{~mL}, 9.86$ $\mathrm{mmol})$ was added dropwise to a solution of $(2 R, 5 S)$-5-isopropyl-3,6-dimethoxy-2(4'-benzyloxyphenethyl)-2,5-dihydropyrazine $(3.33 \mathrm{~g}, 9.38 \mathrm{mmol})$ in freshly distilled THF $(47 \mathrm{~mL})$ at $-78^{\circ} \mathrm{C}$ (dry ice/acetone). The solution was stirred at $-78^{\circ} \mathrm{C}$ for $15 \mathrm{~min}$, where it had turned dark yellow. Methyl iodide $(1.17 \mathrm{~mL}, 18.79 \mathrm{mmol})$ was added dropwise. The solution was stirred for a further $30 \mathrm{~min}$ at $-78^{\circ} \mathrm{C}$ then allowed to slowly warm to $-15^{\circ} \mathrm{C}$ over $4 \mathrm{~h}$. The reaction mixture was quenched with saturated aqueous sodium bicarbonate solution and allowed to warm to room temperature. The THF was removed under reduced pressure and the residue extracted with dichloromethane $(\times 4)$. The organic extracts were combined and dried $\left(\mathrm{Na}_{2} \mathrm{SO}_{4}\right)$. The solvent was removed under reduced pressure and the crude material was purified by flash chromatography on silica gel, eluting with $2 \%$ ethyl acetate $/ n$-hexane, to afford the product as a clear colourless oil ( $1.55 \mathrm{~g}, 45 \%)$, with all analytical data matching that reported in the literature $e^{27} \cdot[\alpha]_{D}^{25.0^{\circ} \mathrm{C}}=-6(0.5$, $\left.\mathrm{CHCl}_{3}\right) ;{ }^{1} \mathrm{H} \mathrm{NMR}\left(300 \mathrm{MHz} ; \mathrm{CDCl}_{3}\right) \delta 0.70(\mathrm{~d}, J=6.8 \mathrm{~Hz}, 3 \mathrm{H}), 1.12(\mathrm{~d}, J=6.8 \mathrm{~Hz}$, $3 \mathrm{H}), 1.30(\mathrm{~s}, 3 \mathrm{H}), 1.85(\mathrm{td}, J=5.1,7.7 \mathrm{~Hz}, 1 \mathrm{H}), 2.08(\mathrm{td}, J=4.3,8.6 \mathrm{~Hz}, 1 \mathrm{H})$, $2.25(\mathrm{td}, J=4.3,8.8 \mathrm{~Hz}, 1 \mathrm{H}), 2.34-2.48(\mathrm{~m}, 2 \mathrm{H}), 3.70(\mathrm{~s}, 3 \mathrm{H}), 3.71(\mathrm{~s}, 3 \mathrm{H}), 3.93(\mathrm{~d}$ $J=3.3 \mathrm{~Hz}, 1 \mathrm{H}), 5.04(\mathrm{~s}, 2 \mathrm{H}), 6.87-6.90(\mathrm{~m}, 2 \mathrm{H}), 7.06-7.09(\mathrm{~m}, 2 \mathrm{H}), 7.29-7.44(\mathrm{~m}$, $5 \mathrm{H}) ;{ }^{13} \mathrm{C}$ NMR $\left(75 \mathrm{MHz} ; \mathrm{CDCl}_{3}\right) \delta 17.1,19.7,28.7,30.7,30.8,42.9,52.4,58.4,60.5$, $70.2,114.8,127.6,128.0,128.7,129.4,135.2,137.4,157.0,162.1,165.7 ; \mathrm{IR}(\mathrm{NaCl}$, neat) $1694 \mathrm{~cm}^{-1}$; HRMS (ESI-MS): $\mathrm{m} / z$ calcd for $\mathrm{C}_{25} \mathrm{H}_{33} \mathrm{~N}_{2} \mathrm{O}_{3}[\mathrm{M}+\mathrm{H}]^{+} 409.2491$, found 409.2490

Methyl (2S)-2-amino-4-(4'-benzyloxyphenyl)-2-methylbutanoate. A solution of trifluoroacetic acid $(15 \mathrm{~mL}, 0.20 \mathrm{~mol})$ in water $(30 \mathrm{~mL})$ was added dropwise to a solution of (2S,5S)-5-isopropyl-3,6-dimethoxy-2-(4'-benzyloxyphenethyl)-2methyl-2,5-dihydropyrazine $(1.48 \mathrm{~g}, 4.01 \mathrm{mmol})$ in acetonitrile $(100 \mathrm{~mL})$. The solution was stirred at room temperature for $4 \mathrm{~h}$ after which the acetonitrile was removed under reduced pressure. The residue was diluted with water and neutralised with portions of solid sodium bicarbonate, then extracted with dichloromethane ( $\times 4)$. The organic extracts were combined and dried $\left(\mathrm{Na}_{2} \mathrm{SO}_{4}\right)$. The solvent was removed under reduced pressure and the crude material was purified by flash chromatography on silica gel, eluting with ethyl acetate, to afford the product as a clear colourless oil $(0.90 \mathrm{~g}, 72 \%)$, with all analytical data matching that reported in the literature $e^{27} \cdot[\alpha]_{D}^{23.5^{\circ} \mathrm{C}}=+12\left(0.5, \mathrm{CHCl}_{3}\right) ;{ }^{1} \mathrm{H}$ NMR $(300 \mathrm{MHz}$; $\left.\mathrm{CDCl}_{3}\right) \delta 1.37(\mathrm{~s}, 3 \mathrm{H}), 1.80-1.90(\mathrm{~m}, 1 \mathrm{H}), 1.96-2.06(\mathrm{~m}, 1 \mathrm{H}), 2.41-2.51(\mathrm{~m}, 1 \mathrm{H})$ 2.55-2.65 (m, 1H), $3.70(\mathrm{~s}, 3 \mathrm{H}), 5.04(\mathrm{~s}, 2 \mathrm{H}), 6.88-6.91(\mathrm{~m}, 2 \mathrm{H}), 7.07-7.10(\mathrm{~m}, 2 \mathrm{H})$ 7.31-7.44 (m, 5H); ${ }^{13} \mathrm{C}$ NMR $\left(75 \mathrm{MHz} ; \mathrm{CDCl}_{3}\right) \delta 26.6,29.9,43.1,52.3,57.8,70.1$, $114.9,127.5,127.9,128.6,129.3,134.0,137.2,157.1,178.0$; IR ( $\mathrm{NaCl}$, neat) $1733 \mathrm{~cm}^{-1}$; HRMS (ESI-MS): $\mathrm{m} / z$ calcd for $\mathrm{C}_{19} \mathrm{H}_{24} \mathrm{NO}_{3}[\mathrm{M}+\mathrm{H}]^{+} 314.1756$ found 314.1754 .

(2S)-2-amino-4-(4'-benzyloxyphenyl)-2-methyl-1-butanol (G024). Lithium aluminium hydride $(0.15 \mathrm{~g}, 3.95 \mathrm{mmol})$ was added as a solid in one portion to a solution of methyl (2S)-2-amino-4-(4'-benzyloxyphenyl)-2-methylbutanoate $(0.83 \mathrm{~g}, 2.64 \mathrm{mmol})$ in freshly distilled THF $(40 \mathrm{~mL})$ at $0{ }^{\circ} \mathrm{C}$. The solution was stirred at $0{ }^{\circ} \mathrm{C}$ for $20 \mathrm{~min}$ then the cold bath was removed and the solution stirred at room temperature for $1 \mathrm{~h}$. The reaction was quenched with saturated aqueous sodium sulphate solution and the mixture was extracted with ethyl acetate $(\times 4)$. The organic extracts were combined and washed with saturated aqueous sodium bicarbonate solution, water and brine, then dried $\left(\mathrm{Na}_{2} \mathrm{SO}_{4}\right)$. The solvent was removed under reduced pressure and the crude material was purified by flash chromatography on silica gel, eluting with $2 \%$ methanol/ $4 \%$ triethylamine/ dichloromethane, to afford the product as a white solid $(0.54 \mathrm{~g}, 72 \%)$, with all data matching that reported in the literature ${ }^{27} .[\alpha]_{D}^{25.5^{\circ} \mathrm{C}}=-2\left(0.5, \mathrm{CHCl}_{3}\right)$; M.p.: 196.7-197.6 ${ }^{\circ} \mathrm{C} ;{ }^{1} \mathrm{H}$ NMR $\left(300 \mathrm{MHz} ; \mathrm{CDCl}_{3}\right) \delta 1.13(\mathrm{~s}, 3 \mathrm{H}), 1.61-1.71(\mathrm{~m}, 2 \mathrm{H})$, $2.59(\mathrm{t}, J=8.6 \mathrm{~Hz}, 2 \mathrm{H}), 3.34(\mathrm{dd}, J=7.5,10.3 \mathrm{~Hz}, 1 \mathrm{H}), 5.04(\mathrm{~s}, 2 \mathrm{H}), 6.90(\mathrm{dd}, J=$ 2.1, 4.6 Hz, 2H), 7.09-7.12 (m, 2H), 7.29-7.45 (m, 5H); ${ }^{13} \mathrm{C}$ NMR $(75 \mathrm{MHz}$; $\left.\mathrm{CDCl}_{3}\right) \delta 24.6,29.5,42.2,53.1,70.2,70.3,115.0,127.6,128.0,128.7,129.3,134.8$, 137.3, 157.1; IR ( $\mathrm{NaCl}$, neat) $3425 \mathrm{~cm}^{-1}$; HRMS (ESI-MS): $\mathrm{m} / z$ calcd for $\mathrm{C}_{16} \mathrm{H}_{28} \mathrm{NO}_{4}[\mathrm{M}+\mathrm{H}]^{+}$286.1807, found 286.1807

(2S)-t-butyl(1-hydroxy-4-(4'-benzyloxyphenyl)-2-methylbutan-2-yl)carbamate. Di-t-butyl dicarbonate $(0.42 \mathrm{~g}, 1.94 \mathrm{mmol})$ was added as a solid in one portion to a mixture of (2S)-2-amino-4-(4'-benzyloxyphenyl)-2-methyl-1-butanol $(0.36 \mathrm{~g}, 1.28 \mathrm{mmol})$ in saturated aqueous sodium bicarbonate solution $(12.8 \mathrm{~mL})$ and ethyl acetate $(12.8 \mathrm{~mL})$. The mixture was heated at $70{ }^{\circ} \mathrm{C}$ for $16 \mathrm{~h}$ then allowed to cool to room temperature. The solution was diluted with water and extracted with ethyl acetate $(\times 3)$. The organic extracts were combined and washed with brine, then dried $\left(\mathrm{Na}_{2} \mathrm{SO}_{4}\right)$. The solvent was removed under reduce pressure and the crude material was purified by flash chromatography on silica gel, eluting with $30 \%$ ethyl acetate $/ n$-hexane, to afford the product as a white solid $(0.51 \mathrm{~g}$, quant $)$, with all analytical data matching that reported in the literature ${ }^{61} \cdot[\alpha]_{D}^{25.6^{\circ} \mathrm{C}}=+2$ $\left(0.5, \mathrm{CHCl}_{3}\right) ;{ }^{1} \mathrm{H}$ NMR $\left(400 \mathrm{MHz} ; \mathrm{CDCl}_{3}\right) \delta 1.22(\mathrm{~s}, 3 \mathrm{H}), 1.44(\mathrm{~s}, 9 \mathrm{H}), 1.80-1.88$ (m, $1 \mathrm{H}), 1.99-2.06(\mathrm{~m}, 1 \mathrm{H}), 2.53(\mathrm{td}, J=7.7,12.2 \mathrm{~Hz}, 1 \mathrm{H}), 2.63(\mathrm{td}, J=5.2,12.0$ $\mathrm{Hz}, 1 \mathrm{H}), 3.62-3.72(\mathrm{~m}, 2 \mathrm{H}), 4.06(\mathrm{br} \mathrm{s}, 1 \mathrm{H}), 4.62(\mathrm{~s}, 1 \mathrm{H}), 5.04(\mathrm{~s}, 2 \mathrm{H}), 6.89-6.91(\mathrm{~m}$, $2 \mathrm{H}), 7.10-7.12(\mathrm{~m}, 2 \mathrm{H}), 7.30-7.44(\mathrm{~m}, 5 \mathrm{H})$.

(2S)-t-butyl(1-hydroxy-4-(4'-hydroxyphenyl)-2-methylbutan-2-yl)carbamate Palladium on carbon (44 mg, 10 wt. \%) was added to a solution of (2S)-t-butyl(1hydroxy-4-(4'-benzyloxyphenyl)-2-methylbutan-2-yl)carbamate (0.44 g, 1.15 $\mathrm{mmol})$ in dry methanol $(30 \mathrm{~mL})$ at room temperature. A hydrogen balloon was attached to the flask and the flask was evacuated and purged with hydrogen $(\times 3)$. The solution was stirred at room temperature for $18 \mathrm{~h}$. The reaction mixture was diluted with dichloromethane and filtered through a short pad of Celite, eluting with dichloromethane. The solvent was removed under reduced pressure to afford the product as a white solid $(0.34 \mathrm{~g}$, quant $)$, with all the analytical data matching that reported in the literature $e^{61} .[\alpha]_{D}^{25.6^{\circ} \mathrm{C}}=+5\left(0.5, \mathrm{CHCl}_{3}\right) ; 1 \mathrm{H} \mathrm{NMR}(300 \mathrm{MHz}$; $\left.\mathrm{CDCl}_{3}\right) \delta 1.21(\mathrm{~s}, 3 \mathrm{H}), 1.44(\mathrm{~s}, 9 \mathrm{H}), 1.79-1.87(\mathrm{~m}, 1 \mathrm{H}), 2.04(\mathrm{td}, J=5.0,13.4 \mathrm{~Hz}$ $1 \mathrm{H}), 2.50(\mathrm{td}, J=4.9,13.3 \mathrm{~Hz}, 1 \mathrm{H}), 2.59(\mathrm{td}, J=5.1,12.5 \mathrm{~Hz}, 1 \mathrm{H}), 3.63-3.76(\mathrm{~m}$, $2 \mathrm{H}), 4.30(\mathrm{~s}, 1 \mathrm{H}), 4.65(\mathrm{~s}, 1 \mathrm{H}), 5.33(\mathrm{br} \mathrm{s}, 1 \mathrm{H}), 6.75(\mathrm{dd}, J=2.1,6.4 \mathrm{~Hz}, 2 \mathrm{H})$, 7.02-7.04 (m, 2H).

\section{(2S)-2-amino-4-(4' -(3,4-dichlorobenzyloxy)phenyl)-2-methylbutan-1-ol}

(P053). 3,4-Dichloro-benzyl bromide ( $20 \mathrm{mg}, 81.3 \mu \mathrm{mol})$ was added dropwise to a suspension of (2S)-t-butyl(1-hydroxy-4-(4'-hydroxyphenyl)-2-methylbutan-2-yl) carbamate $(24 \mathrm{mg}, 81.3 \mu \mathrm{mol})$ and potassium carbonate $(34 \mathrm{mg}, 0.25 \mathrm{mmol})$ in dry DMF $(0.8 \mathrm{~mL})$. The suspension was stirred at room temperature for $15 \mathrm{~h}$. The solution was diluted with water and extracted with ethyl acetate $(\times 3)$. The organic extracts were combined and washed with water and brine, then dried $\left(\mathrm{Na}_{2} \mathrm{SO}_{4}\right)$. The solvent was removed under reduced pressure and the crude material was purified by flash chromatography on silica gel, eluting with $30 \%$ ethyl acetate/nhexane. After dissolving the purified material in methanol $(0.5 \mathrm{~mL})$, a solution of $2 \mathrm{M}$ methanolic hydrochloric acid $(0.12 \mathrm{~mL}, 0.24 \mathrm{mmol})$ was added dropwise to it and the resulting solution was heated at reflux for $4 \mathrm{~h}$. After cooling to room temperature, the solvent was removed under reduced pressure. The residue was dissolved in chloroform and washed with saturated aqueous sodium bicarbonate solution $(\times 2)$ and brine, then dried $\left(\mathrm{Na}_{2} \mathrm{SO}_{4}\right)$. The solvent was removed under reduced pressure to afford the product as a white solid $(16 \mathrm{mg}, 57 \%) .[\alpha]_{D}^{25.5^{\circ} \mathrm{C}}=-2$ $\left(0.5, \mathrm{CHCl}_{3}\right) ;{ }^{1} \mathrm{H}$ NMR $\left(300 \mathrm{MHz} ; \mathrm{CDCl}_{3}\right) \delta 1.15(\mathrm{~s}, 3 \mathrm{H}), 1.63-1.77(\mathrm{~m}, 2 \mathrm{H}), 1.83$ $($ br s, $3 \mathrm{H}), 2.60(\mathrm{t}, J=8.5 \mathrm{~Hz}, 2 \mathrm{H}), 3.35(\mathrm{~d}, J=10.8 \mathrm{~Hz}, 1 \mathrm{H}), 3.41(\mathrm{~d}, J=10.8 \mathrm{~Hz}$, 
$1 \mathrm{H}), 4.98$ (s, 2H), 6.85-6.87 (m, 2H), 7.10-7.13 (m, 2H), 7.24-7.35 (m, 1H), 7.44 $(\mathrm{d}, J=8.3 \mathrm{~Hz}, 1 \mathrm{H}), 7.53(\mathrm{~d}, J=1.6 \mathrm{~Hz}, 1 \mathrm{H}) ;{ }^{13} \mathrm{C} \mathrm{NMR}\left(75 \mathrm{MHz} ; \mathrm{CDCl}_{3}\right) \delta 24.4$, $29.5,53.1,68.8,70.2,77.4,115.0,126.7,129.3,129.5,130.7,135.2,135.51,135.54$, 137.7, 156.6; IR ( $\mathrm{NaCl}$, neat) $3425 \mathrm{~cm}^{-1}$; HRMS (ESI-MS): $\mathrm{m} / z$ calcd for $\mathrm{C}_{18} \mathrm{H}_{22} \mathrm{NO}_{2} \mathrm{Cl}_{2}[\mathrm{M}+\mathrm{H}]^{+}$354.1027, found 354.1017.

FTY720 and FB1 were purchased from Cayman Chemical Company. For biochemistry and cell treatments, compounds were prepared as stock solutions at $10 \mathrm{mM}$ in DMSO, then diluted in water or cell culture medium.

Ceramide synthase assays. Ceramide synthase assays were carried out using an HPLC-based assay with a fluorescent NBD-dihydrosphingosine substrate ${ }^{62}$. All cell lines used for these assays were originally sourced from ATCC. The enzyme source was extracts of HEK293 cells exogenously expressing human CerS1, 2, and 6; U251 cells expressing human CerS4 (which did not express well in HEK293 cells); and COS cells expressing murine CerS1, 2, and 5. Human CerS expression plasmids (pCMV6 plasmids from Origene) were transfected using FuGene- 6 transfection reagent, and cells were harvested $24 \mathrm{~h}$ after transfection in $20 \mathrm{mM}$ Hepes $\mathrm{pH} 7.4,10 \mathrm{mM} \mathrm{KCl}, 1 \mathrm{mM}$ dithiothreitol, $3 \mathrm{mM} \beta$-glycerophosphate, and EDTA free complete protease inhibitor cocktail (Roche). Cells were sonicated in a Diagenode Bioruptor sonicating bath for $5 \mathrm{~min}$, after which cell extracts were cleared by centrifugation at $800 \times g$ for $10 \mathrm{~min}$. Protein concentration in the supernatant was assayed using the bicinchoninic acid (BCA) assay, and the supernatant stored at $-80^{\circ} \mathrm{C}$. COS cells were infected with lentiviral constructs expressing murine CerS1, 2, or 5, then homogenised as described above.

The reaction buffer consisted of $20 \mathrm{mM}$ Hepes pH 7.4, $25 \mathrm{mM} \mathrm{KCl,} 2 \mathrm{mM}$ $\mathrm{MgCl}_{2}, 0.5 \mathrm{mM}$ dithiothreitol, $0.1 \%$ fatty acid free BSA, $10 \mu \mathrm{M}$ NBDdihydrosphingosine and $50 \mu \mathrm{M}$ fatty acid free BSA. C18:0-CoA was used as the fatty acyl substrate for CerS1 and CerS4; C24:1-CoA for CerS2; and C16:0-CoA for CerS5 and CerS6. All reactions were run in triplicate. Test inhibitors were added, after which reactions were started with the addition of $2.5-25 \mu \mathrm{g}$ lysate protein (optimised depending on the particular CerS isoform being assayed). Assays were run for $30 \mathrm{~min}$ at $37^{\circ} \mathrm{C}$, and stopped with the addition of $200 \mu \mathrm{L}$ methanol. The reaction mixture was transferred to a glass HPLC vial with $300 \mu \mathrm{L}$ fused glass insert (Thermo Fisher Scientific) and NBD-dihydroceramide reaction products were analysed on a Thermo Scientific Surveyor HPLC connected to a Shimadzu RF10AXL fluorescent detector (set to gain of 3). A $3 \times 150 \mathrm{~mm}$ Agilent XDB-C8 column $(5 \mu \mathrm{M}$ pore size) was used. Data was acquired over a $12 \mathrm{~min}$ chromatography run using: solvent A, $0.2 \%$ formic acid, $2 \mathrm{mM}$ ammonium formate in water; solvent $\mathrm{B}, 0.2 \%$ formic acid, $1 \mathrm{mM}$ ammonium formate in methanol. The gradient started at $20: 80 \mathrm{~A} / \mathrm{B}$, increasing to $5: 95 \mathrm{~A} / \mathrm{B}$ over $2 \mathrm{~min}$, then to $100 \% \mathrm{~B}$ over $6 \mathrm{~min}$. The gradient was then held at $100 \% \mathrm{~B}$ for $2 \mathrm{~min}$, before re-equilibration to $20: 80 \mathrm{~A} / \mathrm{B}$ for a further $2 \mathrm{~min}$. Peak areas were integrated using Xcalibur software (Thermo Fisher Scientific).

\section{Sphingosine kinase assays. Sphingosine kinase assays were performed using} fluorescent NBD-dihydrosphingosine ${ }^{63,64}$. Reactions containing $50 \mathrm{mM}$ Hepes $\mathrm{pH}$ 7.4, $0.01 \%$ BSA, $15 \mathrm{mM} \mathrm{MgCl} 2,2 \mathrm{mM}$ ATP, $10 \mu \mathrm{M}$ NBD-dihydrosphingosine, and $10 \mu \mathrm{M}$ FTY720 or P053, were started with addition of $10 \mathrm{ng}$ recombinant human sphingosine kinase 1 or 2 (R\&D Systems), and run for $30 \mathrm{~min}$ at $37^{\circ} \mathrm{C}$. Reactions were stopped with $100 \mu \mathrm{L}$ methanol, and $5 \mu \mathrm{L}$ amounts were resolved on Silica Gel 60 thin layer chromatography (TLC) plates using butanol:acetic acid:water (3:1:1). The fluorescent NBD-dihydrosphingosine 1-phosphate band was quantified using a BioRad ChemiDoc imaging system with excitation by UV light.

\section{Preparation of cortical neurons and quantification of D7-labelled ceramides.} Mouse cortical neurons were prepared from E16 pups $^{65}$ and seeded at $5 \times 10^{6}$ cells/ well in poly-D-lysine coated six-well plates. Two weeks after seeding, neurons were pre-treated for $2 \mathrm{~h}$ with P053, then incubated for a further $1 \mathrm{~h}$ with $1 \mu \mathrm{M}$ deuterated dihydrosphingosine (D7-dhSph). Lipid extraction and quantification of D7ceramide using liquid chromatography-tandem mass spectrometry (LC-MS/MS) ${ }^{34}$ is described below.

Administration of P053 to mice. Male C57BL6/J mice were obtained from the Animal Resources Centre in Perth (WA, Australia). Mice were housed at $22 \pm 1{ }^{\circ} \mathrm{C}$ with a controlled 12:12 h light-dark cycle and had ad libitum access to water and either chow ( $8 \%$ calories from fat) or HFD ( $45 \%$ calories from fat $)^{66}$ for $4-6$ weeks. P053 $(5 \mathrm{mg} / \mathrm{kg})$ was administered daily by oral gavage, with control animals receiving vehicle ( $2 \% \mathrm{DMSO}$ in drinking water). Treatment was commenced at the same time as mice were randomised to dietary groups. The experiments were approved by the UNSW animal care and ethics committee (ACEC 15/48B), and followed guidelines issued by the National Health and Medical Research Council of Australia.

Lipid extraction. Lipids were extracted from frozen tissue samples or cells using a two-phase procedure with methyl-tert-butyl ether (MTBE)/methanol/water $(10: 3: 2.5, \mathrm{v} / \mathrm{v} / \mathrm{v})^{67}$. Frozen tissue samples $(\sim 20 \mathrm{mg})$ were homogenized in $0.2 \mathrm{~mL}$ methanol containing $0.01 \%$ butylated hydroxytoluene (BHT), using a Precellys 24 homogenizer and Cryolys cooling unit (Bertin Technologies) with CK14 (1.4-mm ceramic) beads. The homogenates were spiked with an internal standard mixture comprising 5 nmole 19:0/19:0 phosphatidylcholine and 2 nmole each of 17:0/17:0 phosphatidylethanolamine, 17:0/17:0 phosphatidylserine, 17:0/17:0 d5-diacylglycerol, 17:0/17:0 phosphatidylglycerol, 14:0/14:0/14:0/14:0 cardiolipin, 18:1/12:0 SM, 18:1/17:0 ceramide, 18:1/12:0 glucosylceramide, 18:1/12:0 lactosylceramide, 18:1/ 12:0 sulfatide (all from Avanti Polar Lipids, USA), and 17:0/17:0/17:0 TAG (Cayman Chemical, USA), then transferred to $10 \mathrm{~mL}$ screw cap glass tubes. The homogenization tubes containing beads were then washed with another $0.3 \mathrm{~mL}$ methanol, and this wash was combined with the first methanol extract, after which $1.7 \mathrm{~mL}$ MTBE was added and the samples were sonicated in an ice-cold sonicating water bath (Thermoline Scientific, Australia) for $30 \mathrm{~min}$. Phase separation was induced by addition of $417 \mu \mathrm{L}$ of mass spectrometry-grade water followed by vortexing and centrifugation at $1000 \times g$ for $10 \mathrm{~min}$. The upper organic phase was collected into $5 \mathrm{~mL}$ glass tubes. The lower phase was re-extracted by adding $1 \mathrm{~mL}$ MTBE, $300 \mu \mathrm{L}$ methanol, and $250 \mu \mathrm{L}$ water. The organic phases were combined in the $5 \mathrm{~mL}$ glass tubes and dried under vacuum in a Savant SC210 SpeedVac (Thermo Scientific), then reconstituted in $500 \mu \mathrm{L}$ methanol and stored at $-20^{\circ} \mathrm{C}$ until analysis.

HEK293 cells ( $10^{6}$ cells/treatment) were treated for $24 \mathrm{~h}$ with P053, then washed with PBS and scraped into $0.6 \mathrm{~mL}$ methanol on ice. Lipids were then extracted using MTBE/methanol/water as described above ${ }^{67}$.

P053 quantification. Plasma samples $(20 \mu \mathrm{L})$ were extracted with $200 \mu \mathrm{L}$ methanol containing 20 pmoles $\mathrm{AAL}(\mathrm{S})^{27}$ as the internal standard. The mixtures were vortexed, then sonicated in ice water using a Bioruptor (Diagenode) for $2 \mathrm{~min}$ at 30 $\mathrm{s}$ intervals. Extracts were centrifuged at $1400 \mathrm{rpm}$ for $20 \mathrm{~min}, 4^{\circ} \mathrm{C}$, to clear debris. Supernatants were transferred to $5 \mathrm{~mL}$ glass tubes. The remaining insoluble material was re-extracted with $1 \mathrm{~mL} 80 \%$ methanol as above, and the supernatant combined with the first extract. The extracts were evaporated under vacuum (Savant SC210 SpeedVac, Thermo Scientific). Dried extracts were reconstituted in $200 \mu \mathrm{L}$ of $80 \%$ methanol $/ 0.2 \%$ formic acid and stored at $-20{ }^{\circ} \mathrm{C}$. On the day of analysis, the extracts were vortexed thoroughly and centrifuged at $300 \times g$ for 20 min before transferring $100 \mu \mathrm{L}$ of the supernatant to glass HPLC vials. To extract P053 from tissues, MTBE/methanol/water extraction was performed as described above, with $\mathrm{AAL}(\mathrm{S})$ as the internal standard.

LC-MS/MS was performed on a TSQ Quantum Access triple quadrupole mass spectrometer in positive ion mode, coupled to an Accela UPLC system (Thermo Scientific). Extracts $(20 \mu \mathrm{L})$ were separated on a $2 \times 100 \mathrm{~mm}$ Eclipse XDB-C8 column with $1.8 \mu \mathrm{m}$ particle size (Agilent Technologies), using a 7.5 min binary HPLC gradient: 0 min, $70 \%$ B (20\% A); $1.5 \mathrm{~min}, 70 \% \mathrm{~B} ; 3.5 \mathrm{~min}, 95 \%$ B; $4 \mathrm{~min}, 95 \% \mathrm{~B}$; $4.5 \mathrm{~min}, 70 \% \mathrm{~B}$; $7.5 \mathrm{~min} 70 \% \mathrm{~B}$. Mobile phase A: $2 \mathrm{mM}$ ammonium formate $/ \%$ formic acid in water; mobile phase B: $1 \mathrm{mM}$ ammonium formate $/ 1 \%$ formic acid in methanol. The flow rate was $0.4 \mathrm{~mL} \mathrm{~min}^{-1}$, increasing to $0.5 \mathrm{~mL} \mathrm{~min}^{-1}$ from $5-7 \mathrm{~min}$, and column oven $30^{\circ} \mathrm{C}$. P053 was quantified using an external standard curve covering the range $0.1-1000 \mathrm{nM}$, with all concentrations normalised to the 20 pmole AAL(S) internal standard.

Visualisation and quantification of peaks was performed using Thermo Fisher's XCalibur software v2.2. Precursor/product ion $\mathrm{m} / z$ values were as follows: 354.3 and 159.0 for P053; 294.0 and 161.1 for AAL(S); 380.3 and 255.2 for FTY720; 388.2 and 255.2 for FTY720-phosphate.

Lipid quantification. Lipidomic profiling was performed on a QExactive Plus mass spectrometer with heated electrospray ionization (HESI) probe and a Dionex UltiMate 2000 LC pump (Thermo Fisher Scientific). Extracts were resolved on a $2.1 \times 100 \mathrm{~mm}$ Waters Acquity C18 UPLC column $(1.7 \mu \mathrm{m}$ pore size), using a binary gradient in which mobile phase A consisted of acetonitrile:water (60:40), $10 \mathrm{mM}$ ammonium formate, $0.1 \%$ formic acid; and mobile phase B was isopropanol:acetonitrile (90:10), $10 \mathrm{mM}$ ammonium formate, $0.1 \%$ formic acid ${ }^{68}$. The flow rate was $260 \mu \mathrm{L} / \mathrm{min}$ and column oven $55^{\circ} \mathrm{C}$. Data was acquired in full scan/data-dependent $\mathrm{MS}^{2}$ mode (full scan resolution 70,000 FWHM, scan range $400-1200 \mathrm{~m} / \mathrm{z}$ ). The ten most abundant ions in each cycle were subjected to $\mathrm{MS}^{2}$ using an isolation window of $1.4 \mathrm{~m} / z$, collision energy $30 \mathrm{eV}$, resolution 17,500, maximum integration time 110 $\mathrm{ms}$ and dynamic exclusion window $10 \mathrm{~s}$. An exclusion list of background ions was used based on a solvent blank. LipidSearch v4.1.30 software (ThermoFisher Scientific) was used for chromatogram alignment, peak identification and integration. Each lipid peak was manually verified for column elution time and characteristic fragment ions. Data were then exported to an Excel spreadsheet for normalisation of each lipid to its class-specific internal standard, and lipid concentrations were calculated relative to the internal standard.

Targeted quantification of ceramide, HexCer, and SM species in primary neurons, HEK293 cells, mouse brain, and gastrocnemius muscle lipid extracts was performed by LC-MS/MS on a TSQ Access triple quadrupole mass spectrometer (Thermo Fisher Scientific) ${ }^{69}$. Lipids were separated on a $3 \times 150 \mathrm{~mm}$ Agilent XDBC8 column ( $5 \mu \mathrm{M}$ pore size) with a $10 \mathrm{~min}$ isocratic chromatography run using methanol containing $0.2 \%$ formic acid as the mobile phase. Precursor ions were the precise $[\mathrm{M}+\mathrm{H}]$ species for each lipid. The $m / z 184.1$ product ion was used for SM species, and the $264.3 \mathrm{~m} / z$ product ion for ceramide and HexCer species. Deuterated (D7) ceramides were detected as the corresponding $m / z+7$ ions.

Targeted quantification of sphingosine and dihydrosphingosine used the HPLC column and chromatography conditions as described above for P053. Precursor/ 
product ion $\mathrm{m} / \mathrm{z}$ values were: 300.3 and 264.3 for sphingosine; 302.3 and 266.3 for dihydrosphingosine.

Body composition. Body composition (lean mass and fat mass) was determined by EchoMRI-900 Body Composition Analyser (EchoMRI Corporation Pte Ltd, Singapore) in accordance with the manufacturer's instructions.

Glucose metabolism and insulin action. Mice were fasted for $6 \mathrm{~h}$, then received $50 \mathrm{mg}$ stable isotope-labeled glucose $\left(6,6{ }^{2} \mathrm{H}\right.$ glucose, Sigma Aldrich) by oral gavage. Blood glucose was measured with a glucose meter (Accu-Check, Roche, NSW, Australia) prior to and at 15, 30, 45, 60 and 90 min following gavage. Additional blood $(\sim 10 \mu \mathrm{L})$ was collected from the tail tip prior to and at 15 and $60 \mathrm{~min}$ following glucose gavage. These samples were used to perform mass isotopologue analysis of plasma glucose via gas chromatography-mass spectrometry $(\mathrm{GC}-\mathrm{MS})^{70}$. Specifically, plasma glucose was separated into the labelled glucose load and the endogenous (liver/kidney-derived) unlabelled glucose to permit differentiation of glucose disposal from endogenous glucose production (Supplementary Figure 10). Fasting blood insulin was measured using an Ultrasensitive Mouse Insulin ELISA Kit (Crystal Chem, Illinois, USA).

Hyperinsulinemic-euglycemic clamps. At 5 weeks of diet/drug treatment, mice underwent surgery to implant catheters into the left carotid artery and right jugular vein. Catheters were flushed every 1-2 days with heparinised saline to maintain patency. Approximately $6-8$ days post surgery, and after a $\sim 5 \mathrm{~h}$ fast, a hyperinsulinemic-euglycemic clamp was conducted. Mice were conscious, unrestrained and were not handled during the procedure to minimize stress. At $-90 \mathrm{~min}$, a primed $(5 \mu \mathrm{Ci})$ continuous infusion $(0.05 \mu \mathrm{Ci} / \mathrm{min})$ of $\left[3,{ }^{3} \mathrm{H}\right]$-glucose (PerkinElmer) was commenced. Samples were collected at $-30,-20,-10$ and 0 min for basal glucose turnover (Rd) determination. At time 0 , the rate of $\left[3,{ }^{3} \mathrm{H}\right]$-glucose was increased $(0.1 \mu \mathrm{Ci} / \mathrm{min})$ and mice received a primed $(24 \mathrm{mU} / \mathrm{kg})$-continuous $(6 \mathrm{mU} /$ $\mathrm{kg} / \mathrm{min}$ ) infusion of insulin (Actrapid, Novo Nordisk, Copenhagen, Denmark) with euglycemia maintained at $\sim 8 \mathrm{mM}$ during the clamp through variable infusion of glucose ( $25 \%$ solution). Once blood glucose was stable, four sequential samples were taken to determine insulin-stimulated glucose turnover. A bolus of $2\left[{ }^{14} \mathrm{C}\right]$ deoxyglucose $(10 \mu \mathrm{Ci}$; PerkinElmer) was then administered and blood sampled at 2, 5, $10,15,20$ and $30 \mathrm{~min}$, prior to collection of muscles for determination of glucose uptake. Glucose uptake into muscle was determined via the following equation:

$$
\left.R g^{\prime}=\left(2\left[{ }^{14} C\right] \mathrm{DGP}_{\text {tissue }} / \mathrm{AUC} 2\left[{ }^{14} \mathrm{C}\right] \mathrm{DG}_{\text {plasma }}\right) * \text { arterial glucose }\right]
$$

where $2\left[{ }^{14} \mathrm{C}\right]$ DGP $\mathrm{P}_{\text {tissue }}$ is the $2\left[{ }^{14} \mathrm{C}\right] \mathrm{DGP}$ radioactivity in the muscle (in $\mathrm{dpm} / \mathrm{g}$ ), AUC $2\left[{ }^{14} \mathrm{C}\right] \mathrm{DG}_{\mathrm{plasma}}$ is the area under the plasma $2\left[{ }^{14} \mathrm{C}\right] \mathrm{DG}$ disappearance curve (in $\mathrm{dpm} / \mathrm{min} / \mathrm{ml}$ ), and [arterial glucose] is the average blood glucose (in $\mathrm{mM}$ ). Animal numbers for clamps were $n=9$ Chow vehicle, $n=8$ Chow P053, $n=6$ HFD vehicle and $n=6$ HFD P053.

Palmitate oxidation and incorporation into TAG. Tibialis muscles were homogenized in 19 volumes of $250 \mathrm{mM}$ sucrose, $10 \mathrm{mM}$ Tris- $\mathrm{HCl}$ and $1 \mathrm{mM}$ EDTA, $\mathrm{pH}$ 7.4. $50 \mu \mathrm{L}$ of tissue homogenate was incubated with $450 \mu \mathrm{L}$ reaction buffer (111 $\mathrm{mM}$ Sucrose, $11.1 \mathrm{mM}$ Tris- $\mathrm{HCl}, 5.56 \mathrm{mM} \mathrm{KH}_{2} \mathrm{PO}_{4}, 1.11 \mathrm{mM} \mathrm{MgCl}, 88.9 \mathrm{mM}$ $\mathrm{KCl}, 0.22 \mathrm{mM}$ EDTA, $1.11 \mathrm{mM}$ DTT, $2.22 \mathrm{mM}$ ATP, 0.33\% FA-free BSA, $2.22 \mathrm{mM}$ L-carnitine, $0.056 \mathrm{mM} \mathrm{CoA}, 0.11 \mathrm{mM}$ malate, $0.2 \mathrm{mM}$ palmitate, $0.5 \mu \mathrm{Ci} \mathrm{mL}^{-1}[1$ ${ }^{14} \mathrm{C}$ ]-palmitate, $\mathrm{pH} 7.4$ ) for $90 \mathrm{~min}$ at $30^{\circ} \mathrm{C}$, after which reactions were stopped with addition of $100 \mu \mathrm{L}$ of $1 \mathrm{M}$ perchloric acid. ${ }^{14} \mathrm{C}$-labelled $\mathrm{CO}_{2}$ was collected in $100 \mu \mathrm{L}$ of $1 \mathrm{M} \mathrm{NaOH}$ solution for $2 \mathrm{~h} .{ }^{14} \mathrm{C}$-labelled $\mathrm{CO}_{2}$, as well as ${ }^{14} \mathrm{C}$-labelled ASM present in the acidified supernatant, were quantified by scintillation counting.

To quantify palmitate oxidation in intact SkM, whole soleus muscles were dissected tendon to tendon and placed into a vial containing pre-warmed $\left(30^{\circ} \mathrm{C}\right)$ and pre-gassed $\left(95 \% \mathrm{O}_{2}, 5 \% \mathrm{CO}_{2}\right)$ modified Krebs-Henseleit buffer ( $4 \% \mathrm{FA}$-free BSA, $5 \mathrm{mM}$ glucose, $0.5 \mathrm{mM}$ palmitate, $\mathrm{pH}$ 7.4). After a 30 min pre-incubation, muscles were transferred into vials containing $0.5 \mathrm{mCi} / \mathrm{mL}$ of $\left[1^{-14} \mathrm{C}\right]$-palmitate in modified Krebs-Henseleit buffer for another $1 \mathrm{~h}$. The reaction was stopped by removal of the muscles and addition of $1 \mathrm{M}$ perchloric acid to the reaction mixture. ${ }^{14} \mathrm{C}$-labelled $\mathrm{CO}_{2}$ was quantified as described above. The muscles were blotted dry and snap frozen in liquid nitrogen for subsequent lipid extraction and TLC. Muscles were homogenized using a Polytron (Kinematica, Littau-Lucerne, Switzerland) in $1.5 \mathrm{~mL}$ 2:1 chloroform-methanol (v/v). The homogenates were then sonicated in ice water for $15 \mathrm{~min}$, after which $0.3 \mathrm{~mL}$ of distilled water was added, samples were vortexed, and centrifuged at $350 \times \mathrm{g}$ for $10 \mathrm{~min}$ to induce phase separation. The upper aqueous phase was used to quantify ASM, and the lower organic phase was collected and dried under stream of $\mathrm{N}_{2}$, then reconstituted in hexane and spotted on a Silica Gel $60 \mathrm{~F}_{254}$ TLC plate. The TLC plate was developed in hexane/diethyl ether/glacial acetic acid (85:15:1), then air dried. TAG bands were visualised using iodine vapour staining, using an external standard to mark their position, then scraped into vials and quantified by liquid scintillation counting.

Respiratory complex activities in permeabilized muscle fibres. Permeabilized extensor digitorum longus (EDL) fibres were prepared and mitochondrial function

analyzed according to published protocols with some modifications ${ }^{71,72}$. Briefly, EDL muscles were dissected tendon-to-tendon into ice-cold isolation buffer A (10 mM Ca-EGTA buffer, $20 \mathrm{mM}$ imidazole, $20 \mathrm{mM}$ taurine, $49 \mathrm{mM} \mathrm{K-MES,} 3 \mathrm{mM}$ $\mathrm{K}_{2} \mathrm{HPO}_{4}, 9.5 \mathrm{mM} \mathrm{MgCl}_{2}, 5.7 \mathrm{mM}$ ATP, $15 \mathrm{mM}$ phosphocreatine, $1 \mu \mathrm{M}$ leupeptin, $\mathrm{pH} 7.1$ ) and fibres were prepared immediately. Fibre bundles ( $3 \mathrm{mg}$ wet weight) were treated with saponin $(50 \mu \mathrm{g} / \mathrm{mL})$ for $20 \mathrm{~min}$ at $4^{\circ} \mathrm{C}$ and subsequently washed in cold respiration medium B $\left(0.5 \mathrm{mM} \mathrm{EGTA}, 3 \mathrm{mM} \mathrm{MgCl} 2.6 \mathrm{H}_{2} \mathrm{O}, 20 \mathrm{mM}\right.$ taurine, $10 \mathrm{mM} \mathrm{KH}_{2} \mathrm{PO}_{4}, 20 \mathrm{mM}$ HEPES, $0.1 \%$ BSA, $15 \mathrm{mM}$ potassium-lactobionate, $110 \mathrm{mM}$ mannitol, $0.3 \mathrm{mM}$ dithiothreitol, $\mathrm{pH}$ 7.1). Mitochondrial respiratory chain function was analyzed on a Clark-type electrode (Rank Brothers, UK) in situ, in respiration medium $B$ at $37^{\circ} \mathrm{C}$, with the sequential addition of glutamate $(10 \mathrm{mM})$, malate $(5 \mathrm{mM}), \mathrm{ADP}(2 \mathrm{mM})$, rotenone $(0.5 \mu \mathrm{M})$, succinate $(10 \mathrm{mM})$, antimycin $\mathrm{A}$ $(5 \mu \mathrm{M}), \mathrm{N}, \mathrm{N}, \mathrm{N}^{\prime}, \mathrm{N}^{\prime}$-tetramethyl-p-phenylenediamine dihydrochloride $(0.5 \mathrm{mM}$ TMPD), ascorbate $(2 \mathrm{mM})$, and cytochrome $\mathrm{c}(10 \mu \mathrm{M})$. Fibres were recovered after polarography and results were expressed as nmoles of $\mathrm{O}_{2} / \mathrm{min} / \mathrm{mg}$ of tissue. Mitochondrial membrane integrity was verified by cytochrome $c$ release test ${ }^{71,72}$.

Western blotting. Tissues were homogenized in RIPA buffer $(100 \mathrm{mM} \mathrm{NaCl}$, $10 \mathrm{mM}$ Tris, $\mathrm{pH} 7.4,1 \%$ Triton X-100, $0.5 \%$ sodium deoxycholate, $0.1 \% \mathrm{SDS}, 1 \mathrm{mM}$ EDTA, 10\% Glycerol) containing complete protease inhibitor cocktail (Roche) and phosphatase inhibitors ( $3 \mathrm{mM} \beta$-glycerophosphate, $1 \mathrm{mM}$ sodium orthovanadate, $5 \mathrm{mM}$ sodium fluoride) by bead-beating in a Precellys 24 at $4^{\circ} \mathrm{C}$. Extracts were centrifuged at $6500 \mathrm{rpm}$ for $10 \mathrm{~min}$ at $4^{\circ} \mathrm{C}$. Supernatant was collected and protein concentrations determined with the Bicinchoninic acid (BCA) assay (Thermo Scientific). Protein lysates $(15 \mu \mathrm{g})$ were resolved on SDS-PAGE, transferred to polyvinylidene difluoride (PVDF) membrane, and immunoblotted with antibodies against Complex I subunit NADH dehydrogenase (\#ab110242, Abcam), Complex II succinate dehydrogenase subunit B (\#ab14714, Abcam), Complex III subunit Core 2 Ubiquinol-cytochrome $c$ reductase (\#ab14745, Abcam), Complex IV Cytochrome c oxidase (\#11967S, Cell Signaling Technology), Complex V ATP synthase a subunit (\#ab14748, Abcam), PGCla (\#AB3242, Merck Millipore), AMPKa (\#2532S, Cell Signaling Technology), phospho- AMPKa (Thr172) (\#2535S, Cell Signaling Technology), ACC (\#3662S, Cell Signaling Technology), phospho-ACC (Ser 79, which also detects Ser 212 in ACC2, the predominant ACC isoform in SkM) (\#3661S, Cell Signaling Technology) and pan 14-3-3 (\#sc-629, Santa Cruz Biotechnology). All antibodies were used at a dilution of 1:1000. A common loading control was included on every gel to account for variation in relative band intensities between different blots. Antibody-antigen binding was detected using ECL Reagent (GE Healthcare) and imaged on a Fujifilm Las-4000 CCD camera. Bands were quantified by densitometry with Fuji ImageQuantTL software. Full images of blots in Fig. 6 are shown in Supplementary Figure 12.

Enzyme activity assays. Liver and tibialis muscle were homogenized 1:19 (w/v) in $50 \mathrm{mM}$ Tris- $\mathrm{HCl}, 1 \mathrm{mM}$ EDTA, $0.1 \%$ Triton X-100, pH 7.4. The homogenates were subjected to three freeze-thaw cycles and centrifuged for $10 \mathrm{~min}$ at $7000 \times g$ at $4{ }^{\circ} \mathrm{C}$. Supernatants were used to determine the activity of $\mathrm{CS}$ and $\beta \mathrm{HAD}^{66}$. CS activity of extracts was measured spectrophotometrically in $100 \mathrm{mM}$ Tris- $\mathrm{HCl}, \mathrm{pH} 8.2,300$ $\mathrm{mM}$ acetyl CoA, $1 \mathrm{mM} \mathrm{MgCl} 2,1 \mathrm{mM}$ EDTA, $0.1 \mathrm{mM}$ 5,5'-dithio-bis (2-nitrobenzoic acid) (DTNB- $-13.6 \mathrm{mM} / \mathrm{cm}$ at $412 \mathrm{~nm}$ ) and $500 \mathrm{mM}$ oxaloacetate, started by the addition of oxaloacetate. $\beta \mathrm{HAD}$ assays were conducted in $50 \mathrm{mM}$ Imidazole buffer, $\mathrm{pH} 7.4,1 \mathrm{mM}$ EDTA, $0.15 \mathrm{mM}$ NADH $(\varepsilon 6.22 \mathrm{mM} / \mathrm{cm}$ at 340 $\mathrm{nm}$ ) and $0.1 \mathrm{mM}$ acetoacetyl-CoA, started by the addition of acetoacetyl-CoA.

Real-time PCR. PCR (40 cycles) was performed on a LightCycler 480 (Roche) using SensiFAST SYBR mastermix (Bioline). For quantification of CerS1 and CerS2 expression, total RNA was purified from mouse tissues with TRIzol reagent (Sigma-Aldrich), followed by DNase treatment (Promega), and reverse transcribed using random hexamer primers with FirstStrand cDNA synthesis kit (Roche), according to manufacturer's instructions. CerS1 and CerS2 gene expression was determined using a standard curve of $\mathrm{Ct}$ against input cDNA, and normalised to 18s RNA. For mitochondrial genes and transcriptional regulators in SkM, total RNA was prepared with TRIzol, and oligo dT primer was used for reverse transcription. Relative gene expression was determined using the $\Delta \Delta \mathrm{Ct}$ method, with 36B4 and Rpl13 as the reference genes. Samples with excessively high $\mathrm{Ct}$ values (Ct $>30$ for the housekeeping genes) were removed from data analysis (two samples for Fig. 6a, four samples for Fig. 6g). Gene-specific primers were as follows:

Target geneForward primer 18s rRNA GTAACCCGTTGAACCCCATT Cers1 CCACCACACACATCTTTCGC Cers2 ATGCTCCAGACCTTGTATGACT 36B4 GGCTCCAAGCAGATGCAGCAG Rpl13 AGGAGGCGAAACAAGTCCAC mt-Co2 GCCGACTAAATCAAGCAACA mt-Cytb CATTTATTATCGCGGCCCTA mt-Atp6 GACGAACATGAACCCTAAT mt-ND5 ACCATGCTTATCCTCACTTCAG
Reverse primer CCATCCAATCGGTAGTAGCG GGAGCAGGTAAGCGCAGTAG CTGAGGCTTTGGCATAGACAC CCTGATAGCCTTGCGCATCATGG GGAGACTGGCAAAAGCCTTAAAG CAATGGGCATAAAGCTATGG TGTTGGGTTGTTTGATCCTG TACGGCTCCAGCTCATAGT AGTATTTGCGTCTGTTCGTCC 
Table a (continued)

\begin{tabular}{lll} 
Ndufb5 & TTTTCTCACGCGGAGCTTTC & ATAAAGAAGGCTTGACGACAAACA \\
Cox5b & GCTGCATCTGTGAAGAGGACAAC & CAGCTTGTAATGGGTTCCACAGT \\
Atp5o & AGGCCCTTTGCCAAGCTT & TTCTCCTTAGATGCAGCAGAGTACA \\
Cycs & GCAAGCATAAGACTGGACCAAA & TTGTTGGCATCTGTGTAAGAGAATC \\
Nfe212 & TAGATGACCATGAGTCGCTTGC & GCCAAACTTGCTCCATGTCC \\
Nrf1 & GTGCTGATGAAGACTCCCCTT & TGCCGTGGAGTTGAGGATGT \\
Gabpal & TGCCGTGGAGTTGAGGATGT & TCCTGCTCTTTTCTGTAGCCT \\
\hline
\end{tabular}

Mitochondrial DNA. Total DNA was isolated using standard phenol:chloroform extraction, followed by RNase H (NEB) treatment. Relative levels of nuclear and mitochondrial DNA were determined by quantitative PCR on a LightCycler 480 (Roche) using SensiFAST SYBR mastermix (Bioline). Primers for quantification of genomic DNA were: $5^{\prime}$ - GGCTGTATTCCCCTCCATCG-3' ${ }^{\prime}$, and $5^{\prime}$ - CCAGTTGG TAACAATGCCATGT-3'; and mitochondrial DNA: 5' - CCCAGCTACTACCATC ATTCAAGT- $3^{\prime}$, and 5' - GATGGTTTGGGAGATTGGTTGATGT- $3^{\prime 73}$. Calibration curves of $\mathrm{Ct}$ against input DNA were prepared from a pooled sample of mouse SkM DNA, and used to calculate the relative abundance of mitochondrial to nuclear DNA in each sample.

Statistical analyses. HEK293 cell culture experiment: Levels of each lipid in P053treated HEK293 cells were normalised to the mean of the vehicle control group, and each concentration was compared to the control using ANOVA with Dunnett's posttest. $P$ values were adjusted for multiple comparisons in GraphPad PRISM.

Lipidomic analysis of mouse tissue samples: Three comparisons were made for each lipid measured: chow control vs chow + P053, chow control vs HFD control, and HFD control vs HFD + P053. Data were log transformed, then subjected to two-tailed $t$-tests adjusted for multiple comparisons using GraphPad PRISM (Benjamini, Krieger and Yekutieli correction, $Q=1 \%$ ). A single outlier was identified using Grubbs test with high stringency $(P<0.001)$ and removed from the quadriceps sphingosine measurements.

Physiological and biochemical measures: Total ceramide, total sphingosine, and total TAG in SkM, western blotting and gene expression data, and physiological measures, were assessed by two-way ANOVA with diet as one variable and drug as the other. $P$ values for the main effect of diet (i.e., chow vs HFD) and drug (i.e., vehicle vs P053) are reported. Where post-tests were applied, Fisher's Least Significant Difference test was used.

Correlations: Spearman analysis was used to assess correlations between SkM ceramides and adipose tissue mass or \% body fat.

Data availability. Lipidomic datasets for SkM and liver are provided in Supplementary Data File 2. Data used for bar graphs is provided in Supplementary Data File 1. Other raw data files supporting the results and conclusions presented in this manuscript are available from the corresponding authors upon reasonable request.

Received: 7 September 2017 Accepted: 17 July 2018

Published online: 21 August 2018

\section{References}

1. Park, J. W., Park, W. J. \& Futerman, A. H. Ceramide synthases as potential targets for therapeutic intervention in human diseases. Biochim. Biophys. Acta 1841, 671-681 (2014).

2. Merrill, A. H. Jr. Sphingolipid and glycosphingolipid metabolic pathways in the era of sphingolipidomics. Chem. Rev. 111, 6387-6422 (2011).

3. Don, A. S., Lim, X. Y. \& Couttas, T. A. Re-configuration of sphingolipid metabolism by oncogenic transformation. Biomolecules 4, 315-353 (2014).

4. Senkal, C. E., Ponnusamy, S., Bielawski, J., Hannun, Y. A. \& Ogretmen, B. Antiapoptotic roles of ceramide-synthase-6-generated C16-ceramide via selective regulation of the ATF6/CHOP arm of ER-stress-response pathways. FASEB J. 24, 296-308 (2010).

5. Obeid, L. M., Linardic, C. M., Karolak, L. A. \& Hannun, Y. A. Programmed cell death induced by ceramide. Science 259, 1769-1771 (1993).

6. Park, J. W. et al. Ablation of very long acyl chain sphingolipids causes hepatic insulin resistance in mice due to altered detergent-resistant membranes. Hepatology 57, 525-532 (2013).

7. Gao, X. et al. PI3K/Akt signaling requires spatial compartmentalization in plasma membrane microdomains. Proc. Natl Acad. Sci. USA 108, 14509-14514 (2011).

8. Hannun, Y. A. \& Obeid, L. M. Many ceramides. J. Biol. Chem. 286, 27855-27862 (2011)
9. Raichur, S. et al. CerS2 haploinsufficiency inhibits beta-oxidation and confers susceptibility to diet-induced steatohepatitis and insulin resistance. Cell. Metab. 20, 687-695 (2014).

10. Turpin, S. M. et al. Obesity-induced CerS6-dependent C16:0 ceramide production promotes weight gain and glucose intolerance. Cell. Metab. 20, 678-686 (2014).

11. Bergman, B. C. et al. Muscle sphingolipids during rest and exercise: a C18:0 signature for insulin resistance in humans. Diabetologia 59, 785-798 (2016).

12. Gosejacob, D. et al. Ceramide synthase 5 is essential to maintain C16:0ceramide pools and contributes to the development of diet-induced obesity. $J$. Biol. Chem. 291, 6989-7003 (2016).

13. Haughey, N. J., Bandaru, V. V., Bae, M. \& Mattson, M. P. Roles for dysfunctional sphingolipid metabolism in Alzheimer's disease neuropathogenesis. Biochim. Biophys. Acta 1801, 878-886 (2010).

14. Ginkel, C. et al. Ablation of neuronal ceramide synthase 1 in mice decreases ganglioside levels and expression of myelin-associated glycoprotein in oligodendrocytes. J. Biol. Chem. 287, 41888-41902 (2012).

15. Venkataraman, K. et al. Upstream of growth and differentiation factor 1 (uog1), a mammalian homolog of the yeast longevity assurance gene 1 (LAG1), regulates N-stearoyl-sphinganine (C18-(dihydro)ceramide) synthesis in a fumonisin B1-independent manner in mammalian cells. J. Biol. Chem. 277, 35642-35649 (2002).

16. Mizutani, Y., Kihara, A. \& Igarashi, Y. Mammalian Lass6 and its related family members regulate synthesis of specific ceramides. Biochem. J. 390, 263-271 (2005).

17. Ben-David, O. et al. Encephalopathy caused by ablation of very long acyl chain ceramide synthesis may be largely due to reduced galactosylceramide levels. J. Biol. Chem. 286, 30022-30033 (2011).

18. Laviad, E. L. et al. Characterization of ceramide synthase 2: tissue distribution, substrate specificity, and inhibition by sphingosine 1-phosphate. J. Biol. Chem. 283, 5677-5684 (2008).

19. Smith, M. E. et al. Mitochondrial fission mediates ceramide-induced metabolic disruption in skeletal muscle. Biochem. J. 456, 427-439 (2013).

20. Montgomery, M. K. et al. Regulation of glucose homeostasis and insulin action by ceramide acyl-chain length: a beneficial role for very long-chain sphingolipid species. Biochim. Biophys. Acta 1861, 1828-1839 (2016).

21. Williams, R. D., Wang, E. \& Merrill, A. H. Jr. Enzymology of long-chain base synthesis by liver: characterization of serine palmitoyltransferase in rat liver microsomes. Arch. Biochem. Biophys. 228, 282-291 (1984)

22. Tonks, K. T. et al. Skeletal muscle and plasma lipidomic signatures of insulin resistance and overweight/obesity in humans. Obesity 24, 908-916 (2016)

23. Haus, J. M. et al. Plasma ceramides are elevated in obese subjects with type 2 diabetes and correlate with the severity of insulin resistance. Diabetes $\mathbf{5 8}$, 337-343 (2009).

24. Turner, N. et al. Distinct patterns of tissue-specific lipid accumulation during the induction of insulin resistance in mice by high-fat feeding. Diabetologia 56, 1638-1648 (2013).

25. Weir, J. M. et al. Plasma lipid profiling in a large population-based cohort. J. Lipid Res. 54, 2898-2908 (2013).

26. Schiffmann, S. et al. Inhibitors of specific ceramide synthases. Biochimie 94, 558-565 (2012).

27. Toop, H. D., Don, A. S. \& Morris, J. C. Synthesis and biological evaluation of analogs of AAL(S) for use as ceramide synthase 1 inhibitors. Org. Biomol. Chem. 13, 11593-11596 (2015).

28. Bigaud, M., Guerini, D., Billich, A., Bassilana, F. \& Brinkmann, V. Second generation S1P pathway modulators: research strategies and clinical developments. Biochim. Biophys. Acta 1841, 745-758 (2014).

29. Lahiri, S. et al. Ceramide synthesis is modulated by the sphingosine analog FTY720 via a mixture of uncompetitive and noncompetitive inhibition in an Acyl-CoA chain length-dependent manner. J. Biol. Chem. 284, 16090-16098 (2009).

30. Berdyshev, E. V. et al. FTY720 inhibits ceramide synthases and up-regulates dihydrosphingosine 1-phosphate formation in human lung endothelial cells. J. Biol. Chem. 284, 5467-5477 (2009).

31. Topliss, J. G. Utilization of operational schemes for analog synthesis in drug design. J. Med. Chem. 15, 1006-1011 (1972).

32. Topliss, J. G. A manual method for applying the Hansch approach to drug design. J. Med. Chem. 20, 463-469 (1977).

33. Merrill, A. H. Jr., van Echten, G., Wang, E. \& Sandhoff, K. Fumonisin B1 inhibits sphingosine (sphinganine) $\mathrm{N}$-acyltransferase and de novo sphingolipid biosynthesis in cultured neurons in situ. J. Biol. Chem. 268, 27299-27306 (1993).

34. Lim, X. Y., Pickford, R. \& Don, A. S. Assaying ceramide synthase activity in vitro and in living cells using liquid chromatography-mass spectrometry. Methods Mol. Biol. 1376, 11-22 (2016).

35. Lim, K. G. et al. FTY720 analogues as sphingosine kinase 1 inhibitors: enzyme inhibition kinetics, allosterism, proteasomal degradation, and actin rearrangement in MCF-7 breast cancer cells. J. Biol. Chem. 286, 18633-18640 (2011). 
36. Mandala, S. et al. Alteration of lymphocyte trafficking by sphingosine-1phosphate receptor agonists. Science 296, 346-349 (2002).

37. Brinkmann, V. et al. The immune modulator FTY720 targets sphingosine 1phosphate receptors. J. Biol. Chem. 277, 21453-21457 (2002).

38. Hocking, S., Samocha-Bonet, D., Milner, K. L., Greenfield, J. R. \& Chisholm, D. J. Adiposity and insulin resistance in humans: the role of the different tissue and cellular lipid depots. Endocr. Rev. 34, 463-500 (2013).

39. Sentelle, R. D. et al. Ceramide targets autophagosomes to mitochondria and induces lethal mitophagy. Nat. Chem. Biol. 8, 831-838 (2012).

40. Scarpulla, R. C., Vega, R. B. \& Kelly, D. P. Transcriptional integration of mitochondrial biogenesis. Trends Endocrinol. Metab. 23, 459-466 (2012).

41. Yang, Z. F., Drumea, K., Mott, S., Wang, J. \& Rosmarin, A. G. GABP transcription factor (nuclear respiratory factor 2) is required for mitochondrial biogenesis. Mol. Cell. Biol. 34, 3194-3201 (2014).

42. Dinkova-Kostova, A. T. \& Abramov, A. Y. The emerging role of Nrf2 in mitochondrial function. Free Radic. Biol. Med. 88, 179-188 (2015).

43. Reznick, R. M. \& Shulman, G. I. The role of AMP-activated protein kinase in mitochondrial biogenesis. J. Physiol. 574, 33-39 (2006).

44. Wu, Y., Song, P., Xu, J., Zhang, M. \& Zou, M. H. Activation of protein phosphatase $2 \mathrm{~A}$ by palmitate inhibits AMP-activated protein kinase. J. Biol. Chem. 282, 9777-9788 (2007).

45. Kurek, K. et al. Inhibition of ceramide de novo synthesis reduces liver lipid accumulation in rats with nonalcoholic fatty liver disease. Liver Int. 34, 1074-1083 (2014).

46. Chaurasia, B. et al. Adipocyte ceramides regulate subcutaneous adipose browning, inflammation, and metabolism. Cell. Metab. 24, 820-834 (2016).

47. Kasumov, T. et al. Ceramide as a mediator of non-alcoholic fatty liver disease and associated atherosclerosis. PLoS ONE 10, e0126910 (2015).

48. Kagedal, K., Zhao, M., Svensson, I. \& Brunk, U. T. Sphingosine-induced apoptosis is dependent on lysosomal proteases. Biochem. J. 359, 335-343 (2001).

49. Hannun, Y. A. \& Bell, R. M. Lysosphingolipids inhibit protein kinase C: implications for the sphingolipidoses. Science 235, 670-674 (1987).

50. Mullen, T. D. et al. Selective knockdown of ceramide synthases reveals complex interregulation of sphingolipid metabolism. J. Lipid Res. 52, 68-77 (2011).

51. Spassieva, S. D. et al. Ectopic expression of ceramide synthase 2 in neurons suppresses neurodegeneration induced by ceramide synthase 1 deficiency. Proc. Natl Acad. Sci. USA 113, 5928-5933 (2016).

52. Boon, J. et al. Ceramides contained in LDL are elevated in type 2 diabetes and promote inflammation and skeletal muscle insulin resistance. Diabetes 62 , 401-410 (2013).

53. Rolfe, D. F. \& Brown, G. C. Cellular energy utilization and molecular origin of standard metabolic rate in mammals. Physiol. Rev. 77, 731-758 (1997).

54. Hoehn, K. L. et al. Acute or chronic upregulation of mitochondrial fatty acid oxidation has no net effect on whole-body energy expenditure or adiposity. Cell. Metab. 11, 70-76 (2010).

55. Olson, D. P., Pulinilkunnil, T., Cline, G. W., Shulman, G. I. \& Lowell, B. B. Gene knockout of Acc2 has little effect on body weight, fat mass, or food intake. Proc. Natl Acad. Sci. USA 107, 7598-7603 (2010).

56. Vavrova, E. et al. Muscle expression of a malonyl-CoA-insensitive carnitine palmitoyltransferase-1 protects mice against high-fat/high-sucrose diet-induced insulin resistance. Am. J. Physiol. Endocrinol. Metab. 311, E649-E660 (2016).

57. Pewzner-Jung, Y. et al. A critical role for ceramide synthase 2 in liver homeostasis: II. insights into molecular changes leading to hepatopathy. J. Biol. Chem. 285, 10911-10923 (2010).

58. Zigdon, H. et al. Ablation of ceramide synthase 2 causes chronic oxidative stress due to disruption of the mitochondrial respiratory chain. J. Biol. Chem. 288, 4947-4956 (2013).

59. Bauer, R. et al. Schlank, a member of the ceramide synthase family controls growth and body fat in Drosophila. EMBO J. 28, 3706-3716 (2009).

60. Cativiela, C., Serrano, J. L. \& Zurbano, M. M. Synthesis of 3-substituted pentane-2,4-diones: valuable intermediates for liquid crystals. J. Org. Chem. 60, 3074-3083 (1995).

61. Nakamura, T. et al. Asymmetric synthesis of alpha,alpha-disubstituted alpha-amino alcohol derivatives. Tetrahedron-Asymmetry 17, 2781-2792 (2006).

62. Couttas, T. A., Lim, X. Y. \& Don, A. S. A three-step assay for ceramide synthase activity using a fluorescent substrate and HPLC. Lipids 50, 101-109 (2015).

63. Billich, A. \& Ettmayer, P. Fluorescence-based assay of sphingosine kinases. Anal. Biochem. 326, 114-119 (2004).

64. Don, A. S. et al. Essential requirement for sphingosine kinase 2 in a sphingolipid apoptosis pathway activated by FTY720 analogues. J. Biol. Chem. 282, 15833-15842 (2007).
65. Fath, T., Ke, Y. D., Gunning, P., Gotz, J. \& Ittner, L. M. Primary support cultures of hippocampal and substantia nigra neurons. Nat. Protoc. 4, 78-85 (2009).

66. Turner, N. et al. Enhancement of muscle mitochondrial oxidative capacity and alterations in insulin action are lipid species dependent: potent tissue-specific effects of medium-chain fatty acids. Diabetes 58, 2547-2554 (2009).

67. Matyash, V., Liebisch, G., Kurzchalia, T. V., Shevchenko, A. \& Schwudke, D. Lipid extraction by methyl-tert-butyl ether for high-throughput lipidomics. $J$. Lipid Res. 49, 1137-1146 (2008).

68. Hu, C. et al. RPLC-ion-trap-FTMS method for lipid profiling of plasma: method validation and application to 553 mutant mouse model. J. Proteome Res. 7, 4982-4991 (2008).

69. Wong, J. W. H., Abuhusain, H. J., McDonald, K. L. \& Don, A. S. MMSAT: automated quantification of metabolites in selected reaction monitoring experiments. Anal. Chem. 84, 470-474 (2012).

70. Kowalski, G. M. et al. Overexpression of sphingosine kinase 1 in liver reduces triglyceride content in mice fed a low but not high-fat diet. Biochim. Biophys. Acta 1851, 210-219 (2015).

71. Das, A. et al. Impairment of an endothelial $\mathrm{NAD}^{+}-\mathrm{H}_{2} \mathrm{~S}$ signaling network is a reversible cause of vascular aging. Cell 173, 74-89 (2018).

72. Kuznetsov, A. V. et al. Analysis of mitochondrial function in situ in permeabilized muscle fibers, tissues and cells. Nat. Protoc. 3, 965-976 (2008).

73. Santos, J. H., Meyer, J. N., Mandavilli, B. S. \& Van Houten, B. Quantitative PCR-based measurement of nuclear and mitochondrial DNA damage and repair in mammalian cells. Methods Mol. Biol. 314, 183-199 (2006).

\section{Acknowledgements}

This study was supported by National Health and Medical Research Council of Australia (NHMRC) project grant 1126135 (NT, KLH, JCM, CS-P, and ASD), a Diabetes Australia grant (NT, JCM, and ASD), ARC Future Fellowships (NT, CRB), a Prince of Wales Clinical School postgraduate scholarship (XYL), Australian Government APA postgraduate scholarships (HDT, SMB), an Australian Government Research Training Program postgraduate scholarship (ENT), an Alfred Deakin Postdoctoral Fellowship (GMK), and a NHMRC Early Career Fellowship (MKM). We gratefully acknowledge subsidised access to the UNSW Bioanalytical Mass Spectrometry Facility.

\section{Author contributions}

Conceived and supervised the study: A.S.D., N.T., J.C.M. In vitro compound characterisation and lipidomics: X.Y.L., A.S.D., C.S-P. Cultured neurons: T.F. In vivo studies and tissue analysis: N.T., X.Y.L., B.O., A.E.B., C.E.F., H.G., J.T., H.P.M., T.A.C., A.D., G.M.K., C.R.B., K.L.H., G.J.C., M.K.M. Compound design and synthesis: H.D.T., E.N.T., S.M.B., J.C.M. Wrote the paper: A.S.D., N.T., X.Y.L., J.C.M.

\section{Additional information}

Supplementary Information accompanies this paper at https://doi.org/10.1038/s41467018-05613-7.

Competing interests: The authors declare no competing interests.

Reprints and permission information is available online at http://npg.nature.com/ reprintsandpermissions/

Publisher's note: Springer Nature remains neutral with regard to jurisdictional claims in published maps and institutional affiliations.

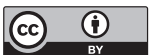

Open Access This article is licensed under a Creative Commons Attribution 4.0 International License, which permits use, sharing, adaptation, distribution and reproduction in any medium or format, as long as you give appropriate credit to the original author(s) and the source, provide a link to the Creative Commons license, and indicate if changes were made. The images or other third party material in this article are included in the article's Creative Commons license, unless indicated otherwise in a credit line to the material. If material is not included in the article's Creative Commons license and your intended use is not permitted by statutory regulation or exceeds the permitted use, you will need to obtain permission directly from the copyright holder. To view a copy of this license, visit http://creativecommons.org/ licenses/by/4.0/.

(C) The Author(s) 2018 